\title{
A simple modeling approach to study the regional impact of a Mediterranean forest isoprene emission on anthropogenic plumes
}

\author{
J. Cortinovis ${ }^{1}$, F. Solmon ${ }^{2}$, D. Serça ${ }^{1}$, C. Sarrat ${ }^{3}$, and R. Rosset $^{1}$ \\ ${ }^{1}$ Laboratoire d'Aérologie, 14 Avenue Edouard Belin, 31400 Toulouse, France \\ ${ }^{2}$ now at: Abdus Salam International Center for Theoretical Physics, PWC group, Trieste, Italy \\ ${ }^{3}$ now at: French Meteorology Office, Toulouse, France
}

Received: 18 June 2004 - Published in Atmos. Chem. Phys. Discuss.: 25 November 2004

Revised: 4 May 2005 - Accepted: 1 July 2005 - Published: 28 July 2005

\begin{abstract}
Research during the past decades has outlined the importance of biogenic isoprene emission in tropospheric chemistry and regional ozone photo-oxidant pollution. The first part of this article focuses on the development and validation of a simple biogenic emission scheme designed for regional studies. Experimental data sets relative to Boreal, Tropical, Temperate and Mediterranean ecosystems are used to estimate the robustness of the scheme at the canopy scale, and over contrasted climatic and ecological conditions. A good agreement is generally found when comparing field measurements and simulated emission fluxes, encouraging us to consider the model suitable for regional application. Limitations of the scheme are nevertheless outlined as well as further on-going improvements. In the second part of the article, the emission scheme is used on line in the broader context of a meso-scale atmospheric chemistry model. Dynamically idealized simulations are carried out to study the chemical interactions of pollutant plumes with realistic isoprene emissions coming from a Mediterranean oak forest. Two types of anthropogenic sources, respectively representative of the Marseille (urban) and Martigues (industrial) French Mediterranean sites, and both characterized by different VOC/NOx are considered. For the Marseille scenario, the impact of biogenic emission on ozone production is larger when the forest is situated in a sub-urban configuration (i.e. downwind distance TOWN-FOREST $<30 \mathrm{~km}$, considering an advection velocity of $4.2 \mathrm{~m} . \mathrm{s}^{-1}$ ). In this case the enhancement of ozone production due to isoprene can reach $+37 \%$ in term of maximum surface concentrations and $+11 \%$ in term of total ozone production. The impact of biogenic emission decreases quite rapidly when the TOWNFOREST distance increases. For the Martigues scenario, the biogenic impact on the plume is significant up to TOWNFOREST distance of $90 \mathrm{~km}$ where the ozone maximum sur-
\end{abstract}

Correspondence to: J. Cortinovis

(jerome.cortinovis@airnormand.fr) face concentration enhancement can still reach $+30 \%$. For both cases, the importance of the $\mathrm{VOC} / \mathrm{NO}_{x}$ ratio in the anthropogenic plume and its evolution when interacting with the forest emission are outlined. In complement to real case studies, this idealized approach can be particularly useful for process and sensitivity studies and constitutes a valuable tool to build regional ozone control strategies.

\section{Introduction}

Biogenic volatile organic compounds (BVOCs) such as isoprene and monoterpenes are known to play key roles in atmospheric chemistry processes that range from local to global scales (Guenther et al., 1995). In particular, the tropospheric production of ozone due to photochemical reactions of nitrogen oxides $\left(\mathrm{NO}_{x}\right)$ can be enhanced by the presence of BVOCs, which are very reactive compared to most anthropogenic VOCs (Stockwell et al., 1997). The impact of biogenic emissions on ozone pollution can be detectable in some urban areas (Chameides et al., 1988) and is very important at rural sites (Tsigaridis and Kanakidou, 2002). Therefore, policies developed to control primary pollutant emissions should always take account of biogenic emissions as much as possible (Roselle et al., 1994). At the regional scale, the spatial extent and dissemination of BVOCs throughout the landscape favor complex interactions with pollutant plumes which determine the regional ozone budget (Sillman et al., 1999). An important aspect of modeling studies investigating these phenomena is the representation of BVOC emissions in simple models (Guenther et al., 1993) designed to simulate emissions for a wide range of vegetation and species. Another important aspect is the modeling of the diversity and the complexity of biogenic source distributions throughout particular landscapes. 
The French Meso-Scale Non-Hydrostatic Chemical model Meso-NH-C (Tulet et al., 1999, 2002; Crassier et al., 2000) was developed in the last few years and has been frequently used for regional anthropogenic pollution studies. The present paper aims at presenting and testing a simple biogenic emissions scheme designed for Meso-NH-C, and studying in a simplified application the interaction of pollutant plumes with a typical isoprene-emitting Mediterranean forest. Sections 2 and 3 describe the model and present a "stand alone" approach where isoprene emission fluxes are simulated using simple parameterizations and hypotheses. Isoprene emission estimates from the resulting BVOCEM scheme are compared to field measurements of isoprene fluxes from boreal, temperate, tropical and Mediterranean forest ecosystems. The objective of the two sections is to evaluate the robustness of the scheme for contrasting conditions, rather than to perform a detailed validation study for each of the different data sets.

In the second part (Sect. 4), the BVOCEM emission scheme is used to simulate isoprene fluxes in the broader context of the Meso-NH-C atmospheric chemistry model. The study of the potential impact of isoprene emissions from a Mediterranean oak forest on anthropogenic polluted plumes is presented using idealized applications. The anthropogenic sources of primary compounds correspond to the French Mediterranean urban areas of Marseille (essentially characterized by traffic emissions) and Martigues (characterized predominantly by industrial sources). The emissions from these two urban areas are characterized by quite different $\mathrm{VOC} / \mathrm{NO}_{x}$ ratios. The influence of distance between town and forest on ozone production is discussed for these two urban areas. These anthropogenic source locations are situated in the region where the ESCOMPTE regional experiment (Cros et al., 2004) took place.

\section{Isoprene emissions modeling}

Numerous studies have modeled isoprene fluxes at the ecosystem level, using sometimes very detailed representation of canopy structure, micro-climate, and chemical processes (see for example Baldocchi et al., 1999). In the present study, the isoprene emission scheme is designed for regional atmospheric chemical modeling. This implies a compromise between the realism of modeling and the necessary restriction in the number of parameters to be used. We adopt here a classic bottom-up approach to derive isoprene fluxes at the canopy level from species emissions factors (Guenther et al., 1993, 1995, 1999). The ecosystem canopy is represented by a simple homogenous layer of leaves comprising of the different species (Solmon et al., 2004). The instantaneous isoprene canopy flux is estimated as:

$F(t)=E P \times E C(t)$, where $t$ stands for time, $F$ is the instantaneous isoprene emission flux at the canopy scale (in $\mu \mathrm{g} \cdot \mathrm{m}^{-2} \cdot \mathrm{h}^{-1}$ ), EP is the canopy emission potential and $E C(t)$ is the canopy environmental correction factor accounting for effect of microclimate (photosynthetically active radiation $(P A R)$ and leaf temperature) on isoprene emissions (Guenther et al., 1993).

For a given vegetation cover, the canopy emission potential is calculated as

$E P=\sum_{i}^{N s p} \tau_{i} . E F_{i} . B m_{i}$,

where Nsp is the number of species in the canopy, $\tau_{i}$ is the cover each species $\left(\mathrm{i}^{\text {th }}\right)$ in the canopy, $\mathrm{EF}_{i}\left(\mu \mathrm{g} \cdot \mathrm{g}_{D W} \cdot \mathrm{m}^{-2}\right)$ is the species leaf level standard emission factor and $\mathrm{Bm}_{i}$ is the dry specific leaf biomass density $\left(\mathrm{g}_{D W} \cdot \mathrm{m}^{-2}\right)$. Once determined, $E P$ is assumed to remain constant for the time scale of our model runs (on the order of days to weeks).

The dynamic environmental correction factor $E C(t)$ factor is calculated as

$E C(t)=\frac{1}{h} \cdot C_{T}\left(T_{S}(t)\right) \cdot \int_{0}^{h} C_{L}(P A R(z, t)) d z$

$C_{L}$ and $C_{T}$ are the emission activity factors depending on the evolving photosynthetically active radiation $(P A R)$ and leaf temperature $\mathrm{T}_{S}$ (Guenther et al., 1993, 1995, 1999). These latter variables are calculated with the Interaction-SolBiosphère-Atmosphère scheme (ISBA-Ags) (Calvet et al., 1998; Noilhan and Planton, 1989). Based on a big-leaf approach, ISBA-Ags solves a single energy budget for the vegetation. The prognostic surface is assumed to represent the mean vegetation layer temperature. This assumption is reasonable if the vegetation cover is dense. In Eq. (3), the $\mathrm{C}_{L}$ term is integrated over the canopy height (h) using the incanopy PAR attenuation scheme presented by Roujean et al., (1996) (see also Solmon et al., 2004). The PAR is generated as a fraction (0.48) of the SW (Solar Wave radiation) forcing. ISBA-Ags and the coupled biogenic emission model (referred hereafter as "BVOCEM") can run in "stand-alone" simulations (i.e., providing an external radiative and meteorological forcing and surface parameterization), or interactively within the Meso-NH meso-scale atmospheric scheme (Solmon et al., 2004).

\section{Stand alone validation}

\subsection{Site descriptions and forcing data}

Four sites representing varying forest ecosystems (in terms of climate and ecology) were considered (Table 1). For each of these four sites, ISBA-Ags was constrained by site-specific meteorological forcings, as well as in-situ estimations of soil water content (root zone). Surface parameters required by the ISBA-Ags (i.e., vegetation cover rate, leaf area index 
Table 1. Main characteristic of isoprene emitting ecosystems considered for validations. Details on isoprene emissions potential estimations: (a) Obtained considering a species emission factor for populus equal to $50 \mu \mathrm{g} \cdot \mathrm{g}_{d w}^{-1} \cdot \mathrm{h}^{-1}$ (Kesselmeier et al., 1999). The resulting value close to the direct estimation of Fuentès et al. (1999) who obtained $28 \mathrm{nmol} . \mathrm{m}^{-2} \cdot \mathrm{s}^{-1}\left(7000 \mu \mathrm{g} \cdot \mathrm{m}^{-2} \cdot \mathrm{h}^{-1}\right)$ from seasonal measurements on the BOR site; (b) Obtained from in situ vegetation screenings giving a mean species emission factors equal to $36,7 \mu \mathrm{g} \cdot \mathrm{g}_{d w}^{-1} \cdot \mathrm{h}^{-1},(\mathrm{Guenther}$ et al., 1994); (c) Obtained from in situ vegetation screening over 82\% (in term of LAI) of present species (Serça et al, 2001); (d) Obtained from an emission factor equal to $22,75 \mu \mathrm{g} \cdot \mathrm{g}_{d w}^{-1} \cdot \mathrm{h}^{-1}$ for Quercus pubescens (Owen et al., 1998, see also text). Juniperus understorey is considered as non emitter.

\begin{tabular}{|c|c|c|c|c|}
\hline Ecosystem & BOR & DUK & TROP & MED \\
\hline Situation & $53,7^{\circ} \mathrm{N} ; 106,2^{\circ} \mathrm{W}$ & $35^{\circ} 58^{\prime} 25^{\prime \prime} \mathrm{N} ; 79^{\circ} 06^{\prime} 55^{\prime \prime} \mathrm{W}$ & $2^{\circ} \mathrm{N} ; 16^{\circ} \mathrm{E}$ & $43^{\circ} 39^{\prime} \mathrm{N} ; 3^{\circ} 41^{\prime} \mathrm{E}$ \\
\hline Characteristics & $\begin{array}{l}\text { Boreal forest, } \\
\text { Homogenous canopy with } \\
\text { understorey cover }\end{array}$ & $\begin{array}{c}\text { Temperate forest, } \\
\text { Dense canopy, flat terrain, } \\
\text { Duke University instrumented site }\end{array}$ & $\begin{array}{l}\text { Dense tropical canopy, } \\
\text { EXPRESSO instrumented site } \\
\text { (Delmas et al., 1999) }\end{array}$ & $\begin{array}{c}\text { Mediterranean forest, } \\
\text { flat terrain (8000 ha), } \\
\text { Light canopy }\end{array}$ \\
\hline Dominant species & $\begin{array}{c}\text { Populus tremuloides, } \\
\text { Populus balsamifera }(<8 \%) \text {, } \\
\text { non emitting understorey }\end{array}$ & $\begin{array}{c}\text { Quercus sp, } \\
\text { Strong emitters }\end{array}$ & Large variability & $\begin{array}{l}\text { Quercus pubescens }(85 \%) \text {, } \\
\text { Juniperus (understorey) }\end{array}$ \\
\hline Height (m) & 22 & $28-32$ & 45 & 6 \\
\hline $\operatorname{LAI}\left(\mathrm{m}^{-2} \cdot \mathrm{m}^{-2}\right)$ & 5.6 (total), 2.4 (emitters) & 5.2 & 6.3 & 2.4 (total) \\
\hline Dry leaf biomass $\left(\mathrm{g}_{d w} \cdot \mathrm{m}^{-2}\right)$ & 144 (emitters) & 472 & - & 228 \\
\hline Isoprene $\mathrm{EP}\left(\mu \mathrm{g} \cdot \mathrm{m}^{-2} \cdot \mathrm{h}^{-1}\right)$ & 7000 (a) & $17300(b)$ & $4443(\mathrm{c})$ & $5185(d)$ \\
\hline Micro-meteorological forcing & $\begin{array}{l}\text { Above canopy radiations, wind, } \\
\text { air temp. and hum., } \\
\text { Net rad., sens and lat. heat fluxes }\end{array}$ & $\begin{array}{l}\text { Above canopy radiations, wind, } \\
\text { air temp. and hum., } \\
\text { Net rad., sens and lat. heat fluxes }\end{array}$ & $\begin{array}{c}\text { Above canopy radiations, wind, } \\
\text { air temp. and hum., } \\
\text { sens and lat. heat fluxes }\end{array}$ & $\begin{array}{l}\text { Above canopy radiations, wind, } \\
\text { air temp. and hum., } \\
\text { sens and lat. heat fluxes }\end{array}$ \\
\hline Isoprene fluxes method & Flux-gradient method & Relaxed Eddy Accumulation & $\begin{array}{l}\text { Relaxed Eddy Accumulation } \\
\text { (Rq. gaps in measurements) }\end{array}$ & Fast isoprene sensor + covariance method \\
\hline Period of measurement & $\begin{array}{c}\text { Days } 203,207 \text { and 215, } \\
\text { August } 1994\end{array}$ & $\begin{array}{c}8 \text { successive days, } \\
\text { June } 1996\end{array}$ & 17-23 March 1996 & 28 June-2 July 2000 \\
\hline References & Fuentès et al., 1999 & $\begin{array}{c}\text { Guenther et al., } 1994 \\
\text { Geron et al., } 1997 \\
\text { Guenther et al., } 1998\end{array}$ & $\begin{array}{l}\text { Klinguer et al., } 1998 \\
\text { Serça et al., } 2001\end{array}$ & - \\
\hline
\end{tabular}

(LAI), height, roughness, albedo; see Calvet et al., 1998; Noilhan and Planton, 1989) were determined from in-situ observations. References describing each experimental site and the data collected at each, as well as corresponding emission potential estimations, are provided in Table 1, except for the last Mediterranean experiment (MED case). This site was monitored using instruments deployed for the ESCOMPTE 2001 regional experiment (Cros et al., 2003). Data collected at several field campaigns, including the BEMA project, have shown that the emission potential for Quercus pubescens is extremely variable (e.g., Kesselmeier et al., 1999). Thus, it was necessary to estimate a representative value of $E F$ during the MED experiment. No leaf-level measurements were performed at the plant level on this ecosystem during the ESCOMPTE project. However, measured canopy level fluxes (collected during the ESCOMPTE experiment) were normalized to standard conditions using the measured $P A R$, air temperature, and emitting biomass, resulting in an emission factor of about $20 \mu \mathrm{g} \cdot \mathrm{g}_{d w}^{-1} \cdot \mathrm{h}^{-1}$. Of course, this estimation does not constitute a direct measurement of emission factor, but it allowed the determination of its probable value. The calculated emission factor is consistent with the range of values found in the literature (22.75$90 \mu \mathrm{g} \cdot \mathrm{g}_{d w}^{-1} \cdot \mathrm{h}^{-1}$ ). Owen et al. (1998) determined an emission factor $22.75 \mu \mathrm{g} \cdot \mathrm{g}_{d w}^{-1} \cdot \mathrm{h}^{-1}$ for Quercus pubescens in a French forest during the BEMA experiment from June to September 1995, (conditions very similar to the MED experiment). This value, which approaches the ecosystem estimation, was used to determine the representative emission potential of $5185 \mu \mathrm{g} \cdot \mathrm{m}^{-2} \cdot \mathrm{h}^{-1}$ reported in Table 1 .

\subsection{Results}

To describe as well as possible the canopy energy budget and surface temperature (Calvet et al., 1998), the leaf mesophylian conductance parameter was first calibrated by minimizing the root mean square error between observed and simulated time series of net radiation and latent and sensible heat fluxes. For the four different databases, the simulated latent and heat fluxes agree reasonably with the measurements, with a total root mean square error varying from $30 \mathrm{~W} . \mathrm{m}^{-2}$ for the BOR case to $70 \mathrm{~W} \cdot \mathrm{m}^{-2}$ for the MED case. For the MED site, the simulation of latent heat flux is more challenging due to the strong controls of Mediterranean plants on transpiration, as well as soil moisture heterogeneity.

Figure 1 displays a time series of modeled and experimental values of isoprene fluxes for the four cases. The temporal evolution of fluxes is in quite good agreement with measurements: the morning activation, diurnal maxima, and evening decrease are generally in phase. Correlation coefficients between modeled and measured isoprene fluxes are 

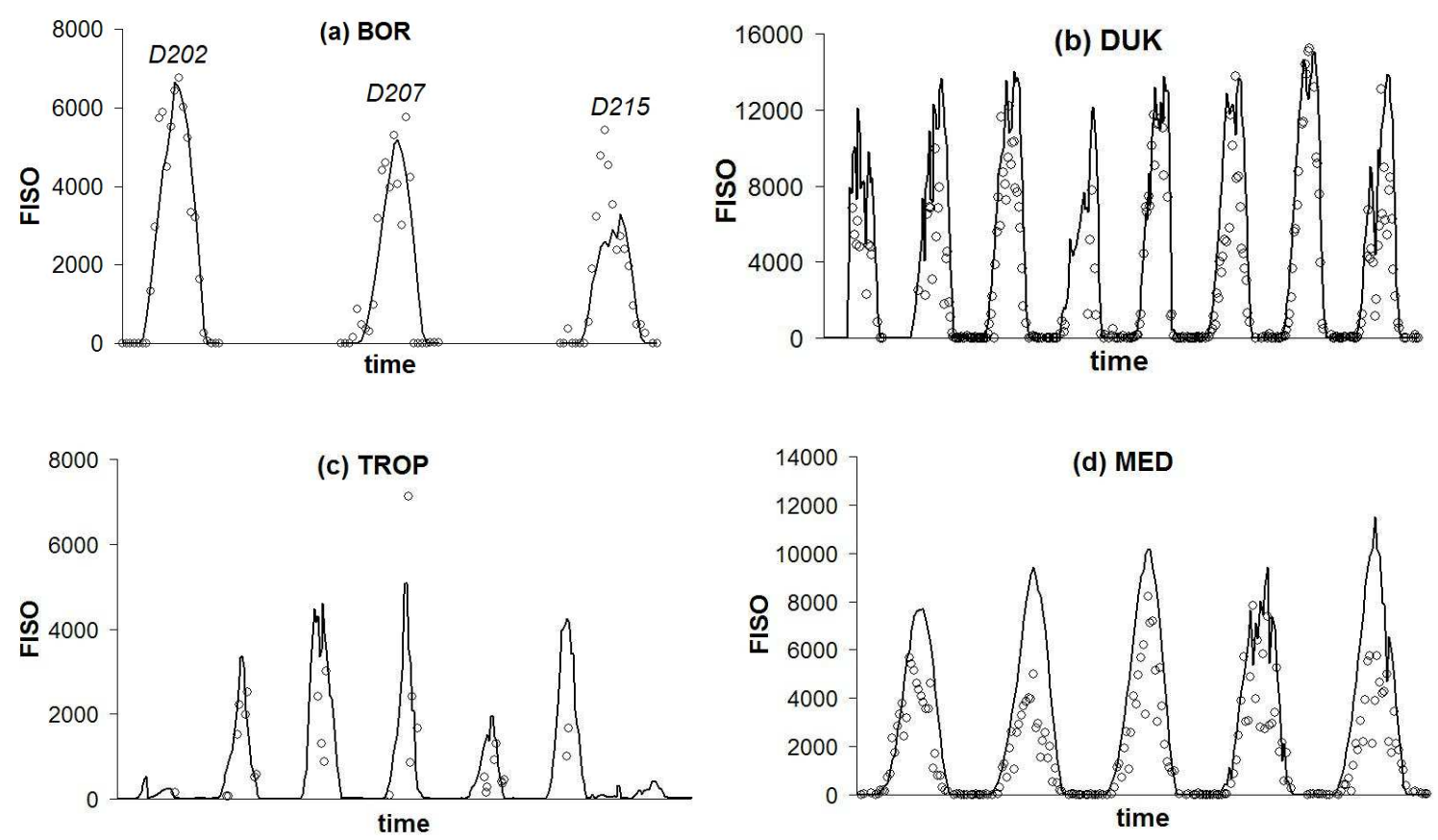

Fig. 1. Simulated isoprene emission fluxes (solid lines) in $\mu \mathrm{g} \cdot \mathrm{m}^{-2} \cdot \mathrm{h}^{-1}$ versus measured emission fluxes (dots) for four contrasted ecosystems. (a) BOReal forest for three separate days; (b) DUKe forest temperate ecosystem for 8 consecutive days; (c) TROPical forest for 6 consecutive days; (d) MEDiterranean forest for five consecutive days. See text and Table 1 for descriptions of these ecosystems.

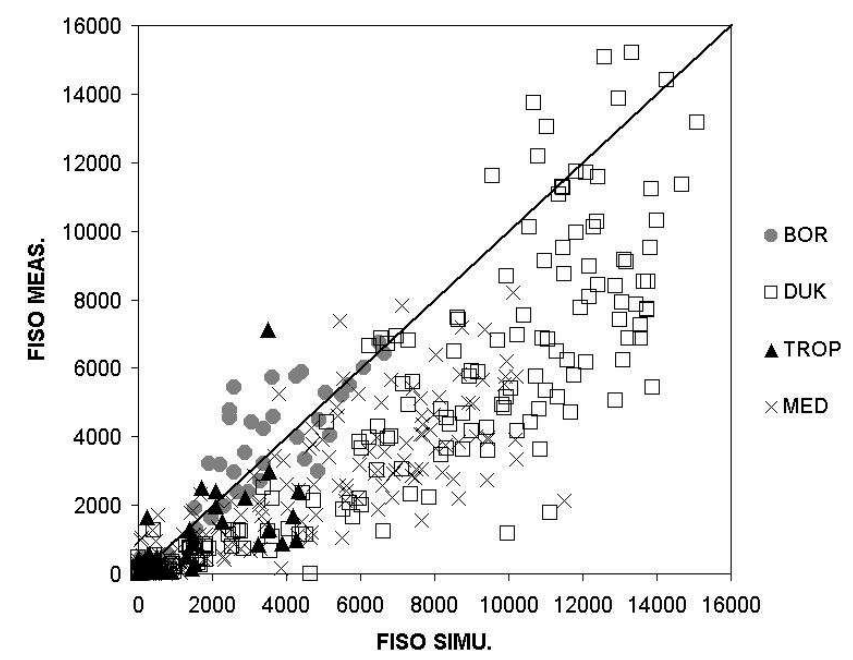

Fig. 2. Global scatter plot of model results versus isoprene flux measurement in the four ecosystems (see Fig. 1 legend) - correlation coeffcients: $\mathrm{r}_{B O R}=0.89, \mathrm{r}_{D U K}=0.91$ and $\mathrm{r}_{M E D}=0.88$.

0.89 for BOR case, 0.91 for the DUK case, and 0.88 for the MED case. Not enough data are available to calculate a reliable correlation coefficient in the TROP case. On Fig. 2, we note that the model tends to systematically overestimate the measurements. A possible cause of this bias lies in the assumption of a single leaf energy balance, which does not account for thermal profile in the canopy (e.g. shade leaves being cooler than sun exposed leaves). For the MED case, the results can be improved by assuming that leaf temperature is equal to the air temperature measured at the same canopy level (which was checked in situ, data not shown).

The model bias may also be the result of uncertain emission potential estimates. Numerous studies outline the large inter- and intra-species variability of emission factors and dry leaf biomass density, as well as the phenologic and seasonal dependencies of these variables (Xiaoshan et al., 2000; Otter et al., 2002). These uncertainties have direct repercussions on emission potentials (Guenther et al., 2000). For the four studied ecosystems, emission potentials have been estimated with in situ measurements and therefore, uncertainties should be minimized.

The isoprene emission flux estimates produced with the simple, stand-alone scheme presented here compares fairly well with measured values, suggesting that this method is suitable for estimating isoprene emissions in regional studies.

\section{Application: chemical impact of a Mediterranean for- est isoprene emissions}

\subsection{The Meso-NH-C model}

The non-hydrostatic meso-scale meteorological model MesoNH is jointly developed by CNRM (Centre National de la Recherche Météorologique - CNRM, France) and Laboratoire d'Aérologie (Centre National de la Recherche 


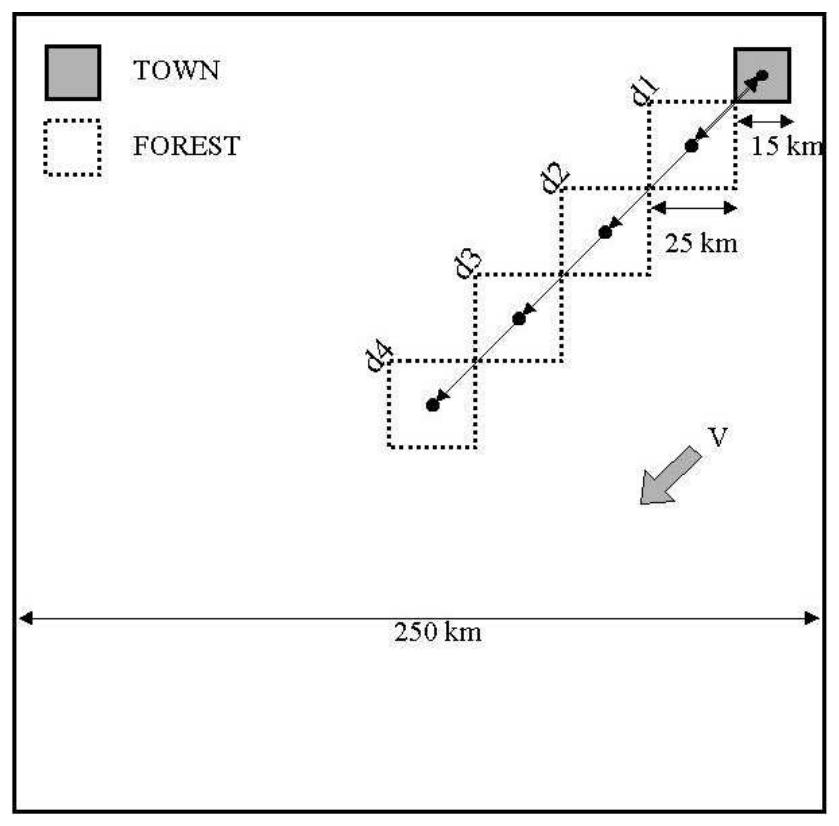

Fig. 3. Schematic configuration of the idealized domain of simulation to study the interactions between of the anthropogenic plume coming from TOWN area and isoprene emission from the FOREST area. $d_{1}$ to $d_{4}$ represent different downwind distances between TOWN and FOREST. The horizontal resolution is $5 \mathrm{~km}$.

Scientifique - CNRS) (Lafore et al., 1998). MesoNH can run with an on-line chemistry option (MesoNH-C) that uses the Regional Lumped Atmospheric Chemical Scheme (ReLACS, Crassier et al., 2000), a reduced version of the Regional Atmospheric Chemistry Mechanism (RACM) model (Stockwell at al., 1998). ReLACS includes 37 species (biogenic hydrocarbons being explicitly differentiated) associated with 128 chemical reactions (Crassier et al., 2000; Tulet et al., 2003). The anthropogenic emissions issued from the GENEMIS inventory are directly prescribed to the model. The BVOCEM model (described in Sect. 2) is implemented in MesoNH-C (Solmon et al., 2004) to calculate biogenic isoprene emissions.

\subsection{The configuration of idealized simulation}

The main objective of the simulations described here was to characterize the impact of biogenic isoprene emissions in a simplified dynamical situation with realistic surface chemical emissions. We considered a flat idealized domain of $250 \mathrm{~km}^{2}$, with a $5 \mathrm{~km}$ horizontal grid resolution and 30 vertical levels with a fine stretched resolution starting at $10 \mathrm{~m}$ above the surface. The top of the domain was set at $10500 \mathrm{~m}$. Three types of surface were defined on this domain (Fig. 3): (i) the TOWN type associated with the town energy budget model of Masson et al. (2000), (ii) a default vegetation associated with a set of surface parameters representative of Mediterranean grassland (Masson et al., 2000), and (iii) a
FOREST cover characterized by the set of surface parameters described and validated in the above-mentioned MED experiment (Sect. 3). The dimensions of the modeled TOWN and the FOREST areas were typical of landscape configurations in Mediterranean regions (e.g., the ESCOMPTE domain). The atmospheric variables (temperature, humidity, and pressure) were initialized with the ECMWF analysis and corresponded to 30 July 2001 . The domain boundary conditions were constrained every $6 \mathrm{~h}$ using the ECMWF analysis. The wind module was set to $4.2 \mathrm{~m} . \mathrm{s}^{-1}$ to simulate realistic advection of primary anthropogenic pollutants to the forest region. The simulations were performed for the period 30 July, 00:00 UT to 31 July, 00:00 UT.

\subsection{Chemical sources and initial conditions}

For TOWN anthropogenic emissions, we considered successively two distinct sources, both provided by the GENEMIS primary compounds database (Wickert et al., 1999) and representative of a typical Mediterranean summer day. The first corresponded to the Marseille town (henceforward referred as $M S$ scenario). The $M S \mathrm{NO}_{x}$ and VOC emissions, characterized by motor vehicle emissions, are shown in Figs. 4a and $4 \mathrm{~b}$. The VOC term in those figures represents the sum of primary organic groups as defined in Crassier et al. (2000). For the $M S$ scenario, the corresponding $\mathrm{VOC} / \mathrm{NO}_{x}$ emission ratio was approximately $5 \mathrm{ppbC/ppb}$ during when emissions were at their daily maximum (Fig. 4c). The second TOWN source was represented by the Martigues area (referred as $M T$ scenario). This urban source was characterized by a substantial industrialized zone and significant car traffic. The $M T$ emissions did not show a strong diurnal cycle when compared to $M S$ urban emissions (Figs. 4a and 4b). The main difference between these TOWN emission sources was the $\mathrm{VOC} / \mathrm{NO}_{x}$ ratio, the average of which was $\sim 2$ for the $M T$ and $\sim 4$ for the $M S$ scenario (Figs. 4c). These anthropogenic emissions were prescribed hourly at the surface on the TOWN delimited area for the model simulations.

The diurnal FOREST isoprene emission was directly calculated by the BVOCEM scheme described above. The diurnal evolution of isoprene emissions corresponded to day 4 in Fig. 1d (see also Sect. 3), which compared realistically with observations.

The initialization of the model chemical fields was based on clean air values for each species of the ReLACS scheme. In particular, the initial homogeneous ozone concentration was set to $40 \mathrm{ppb}$ over the entire model domain. The same clean air characteristics were considered for the boundary conditions. Consequently, the upwind ozone concentrations reaching the TOWN were constant and equal to $40 \mathrm{ppb}$. No specific sensitivity study to these initial and background conditions is presented in this study. However some tests suggested that, at the first order and in our simplified case, the inplume ozone chemistry was mainly controlled by the emissions and that the ozone background value acted only as an 


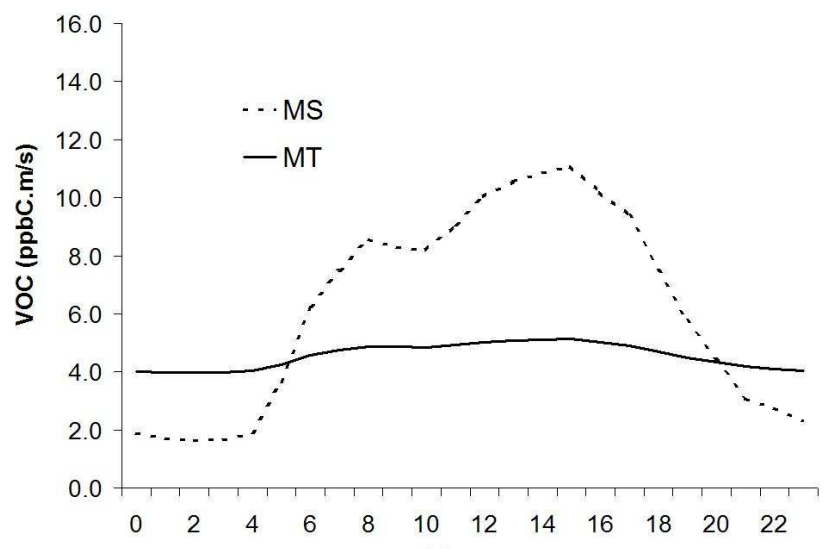

(a)
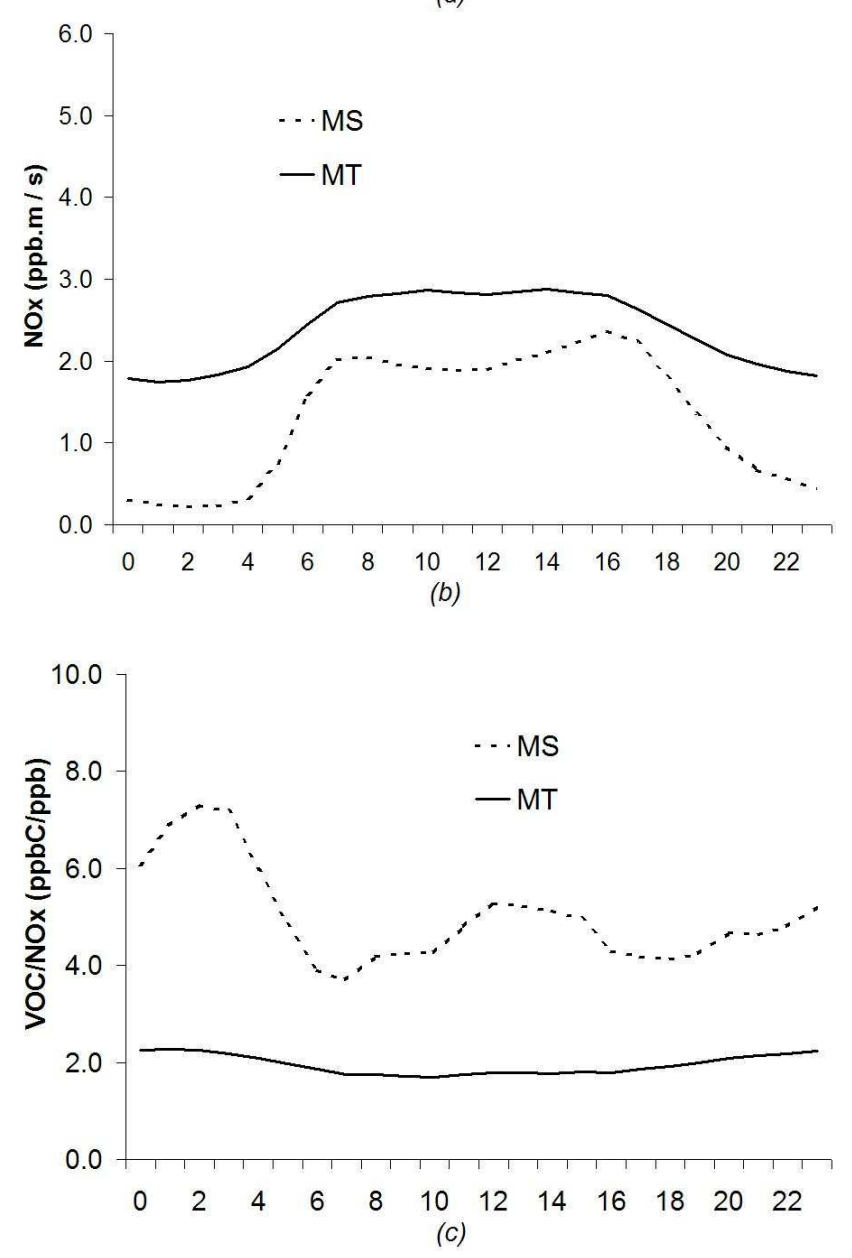

Fig. 4. Chemical characteristics of the anthropogenic sources for the TOWN area. (a) Diurnal evolution of VOC fluxes for Marseille $(M S)$ and Martigues $(M T)$ scenarios; (b) Diurnal evolution of $\mathrm{NO}_{x}$ for $M S$ and $M T$ scenarios; (c) Corresponding $\mathrm{VOC} / \mathrm{NO}_{x}$ ratios.

offset. As described above, the simulation was performed over one day, from 00:00 UT to 12:00 UT. Dynamical and chemical spin up time were very small in this open idealized configuration. The results from 08:00 to 20:00 are discussed

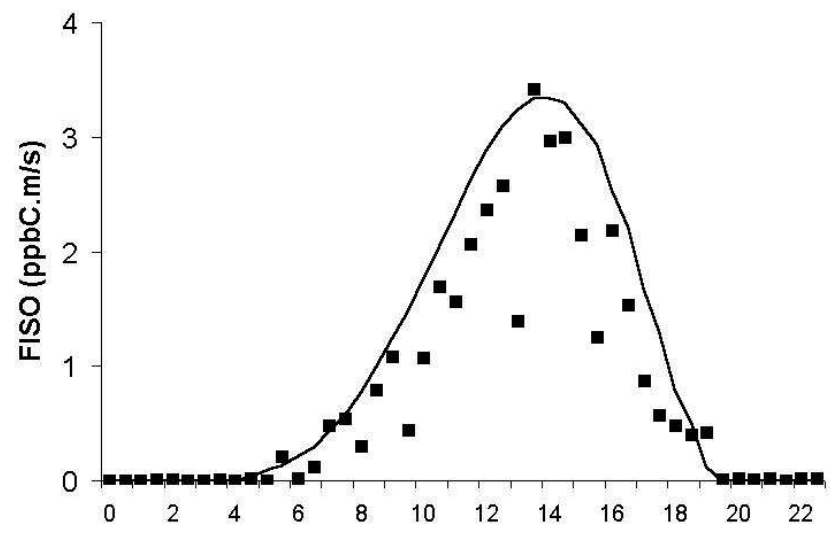

Fig. 5. Isoprene emission flux above the FOREST area for the 3D simulation. Dots represent experimental data collected during the Mediterranean field campaign (see text, Sect. 3).

here.

In order to study the scale of interactions between anthropogenic plumes and biogenic sources, model simulations were performed for using the $M S$ and $M T$ sources. In each case, four different downwind distances (referred as $d_{1}$-the shortest, $d_{2}, d_{3}$ and $d_{4}$-the longest, cf Fig. 3 ) between the FOREST and TOWN area were studied. For each distance, a simulation including isoprene emissions (referred as $B I O$ simulation) and a control simulation without biogenic emissions $(N O B I O)$ was performed, the other conditions being strictly equivalent.

\subsection{Reference anthropogenic plumes}

The results of the NOBIO simulations performed with the $M S$ and $M T$ scenarios showed the development of the ozone in the plume from the anthropogenic sources. These plumes were characterized by surface ozone concentration exceeding the initial clean air value of $\left[\mathrm{O}_{3}\right]=40 \mathrm{ppb}$ (Figs. 6 and 7).

The simulation of ozone from the MS-NOBIO showed a "typical" development over the day with a concentration increase starting around 09:00 UT, and a maximum concentration of $60 \mathrm{ppb}$ reached around 12:00 UT (Fig. 6a). The $\mathrm{VOC} / \mathrm{NO}_{x}$ ratio reached 6.5 in the maximum of the ozone plume (Fig. 6b). As the ozone plume was transported and diluted during the day, the $\mathrm{VOC} / \mathrm{NO}_{x}$ ratio increased downwind of the source (Fig. 6b, 12:00 UT and 15:00 UT). Immediately near and over the anthropogenic TOWN source, the $\mathrm{VOC} / \mathrm{NO}_{x}$ ratio remained low.

The surface ozone concentrations in the MT-NOBIO simulation are shown in Figs. 7a and b. The maximum ozone concentration in the $M T-N O B I O$ simulation occurred at 15:00 UT and at a farther downwind distance than in the $M S$ NOBIO simulation. Since dynamic conditions were equivalent, the difference was related to the larger nighttime anthropogenic emissions in $M T$ scenario (Figs. 4a and b). Until 12:00 UT, the ozone concentration increase was mainly 
$\left[\mathrm{O}_{3}\right]$
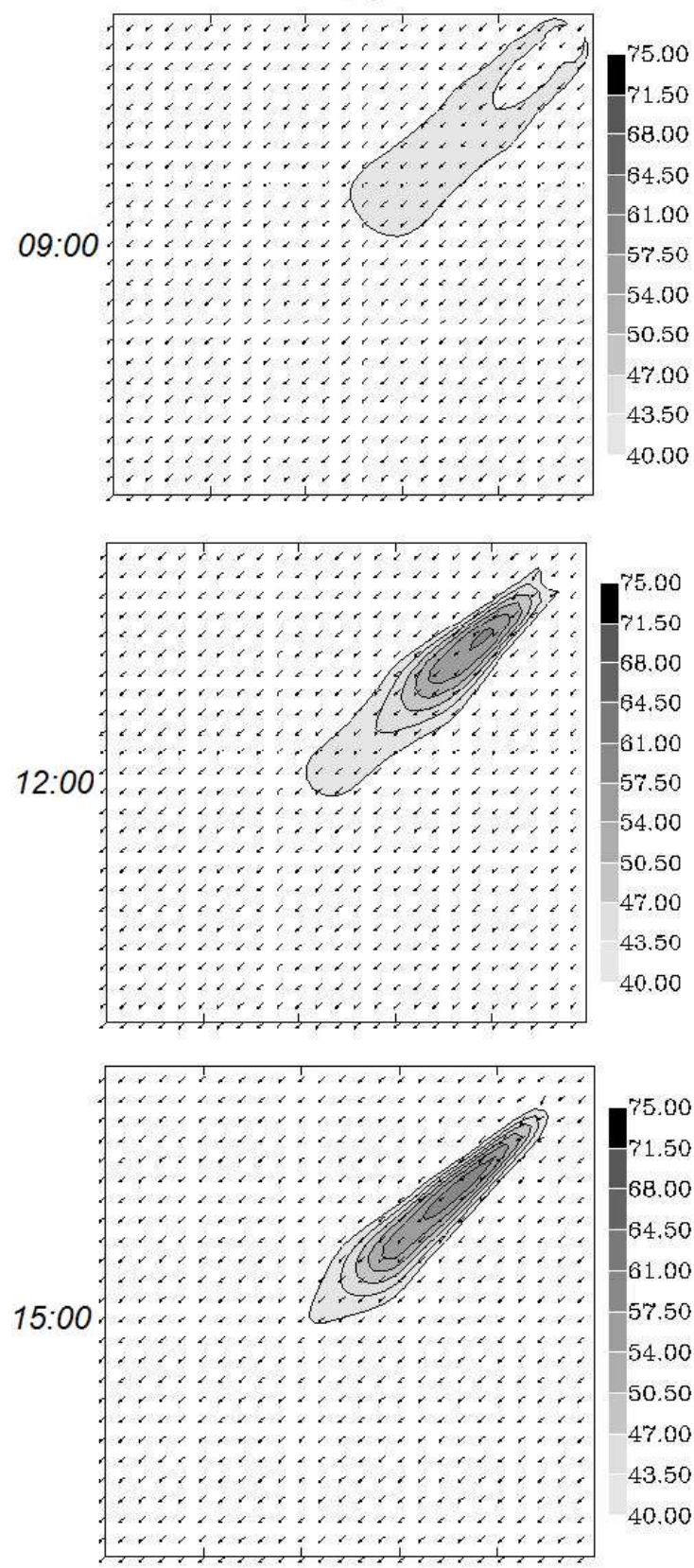

(a)
[VOC/NOX]
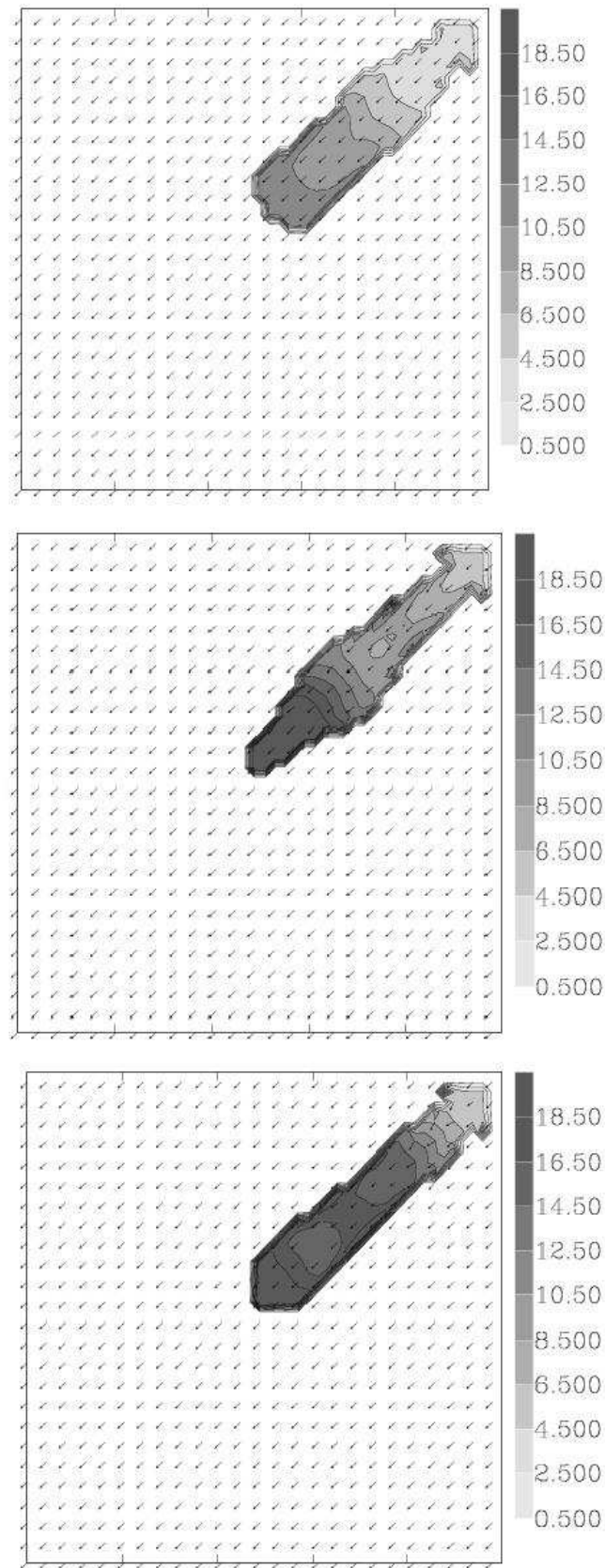

(c)

Fig. 6. Reference simulations without biogenic emissions for the Marseille- $d_{1}$ case (MS-NOBIO). Horizontal section (at $10 \mathrm{~m}$ above ground)

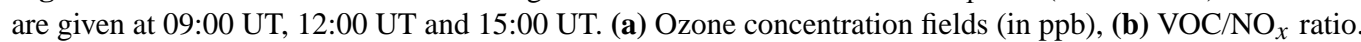

observed at the front and on the edge of the anthropogenic plume (Fig. 7a). The area of relatively low ozone concentrations inside the plume (Fig. 7a) at 09:00 and 12:00 UT immediately downwind of the source) was associated with a low $\mathrm{VOC} / \mathrm{NO}_{x}$ ratio $<2.5$ (Fig. $7 \mathrm{~b}$ ). In this area, the ozone production was inhibited by high $\mathrm{NO}_{x}$ concentrations $\left(\mathrm{NO}_{x}\right.$ - saturated conditions as defined in Sillman et al., 1999). Such effects have been experimentally observed close to strong $\mathrm{NO}_{x}$ sources (e.g., Trainer et al., 1995).

In the following discussion, $N O B I O$ plumes are considered as reference to evaluate the impact of isoprene emissions in $B I O$ simulations. 
$\left[\mathrm{O}_{3}\right]$
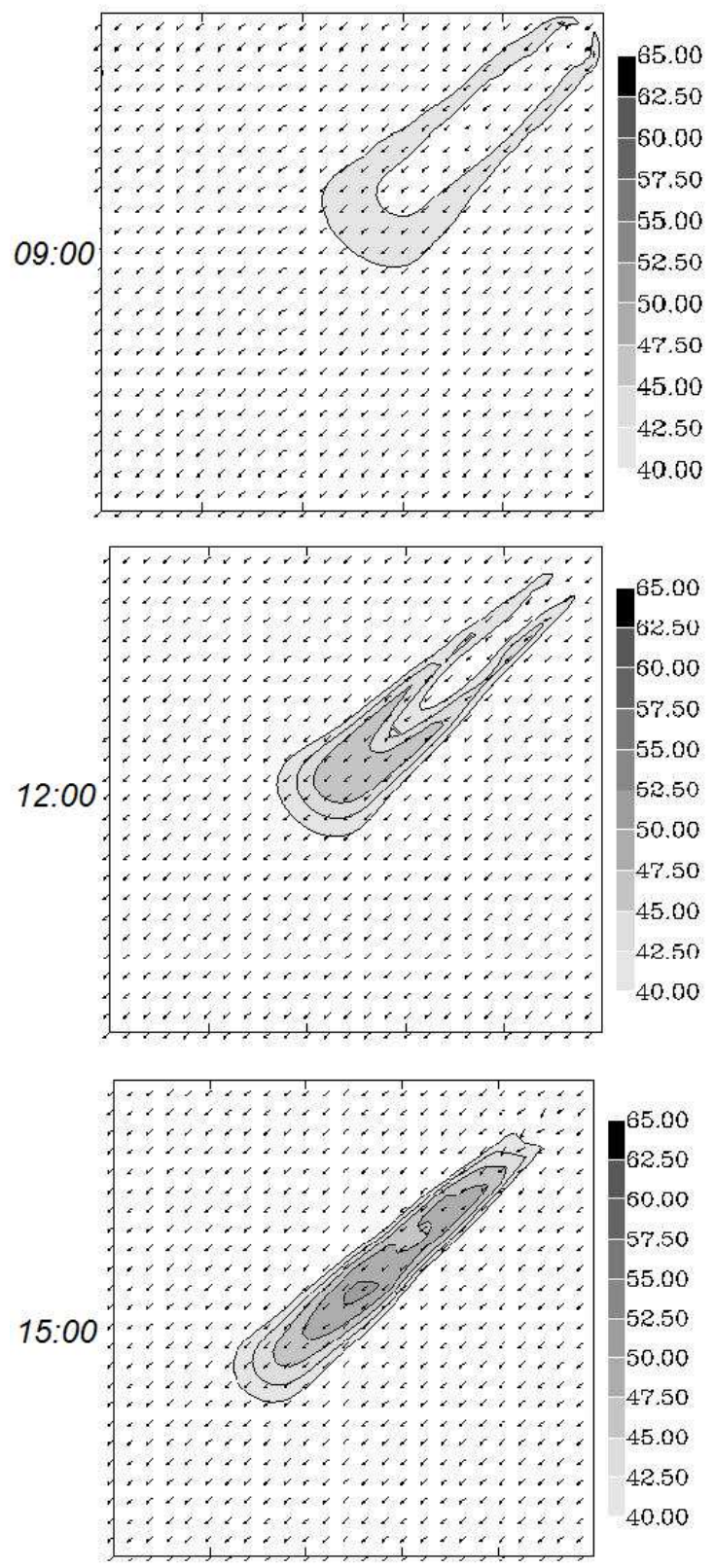

(a)
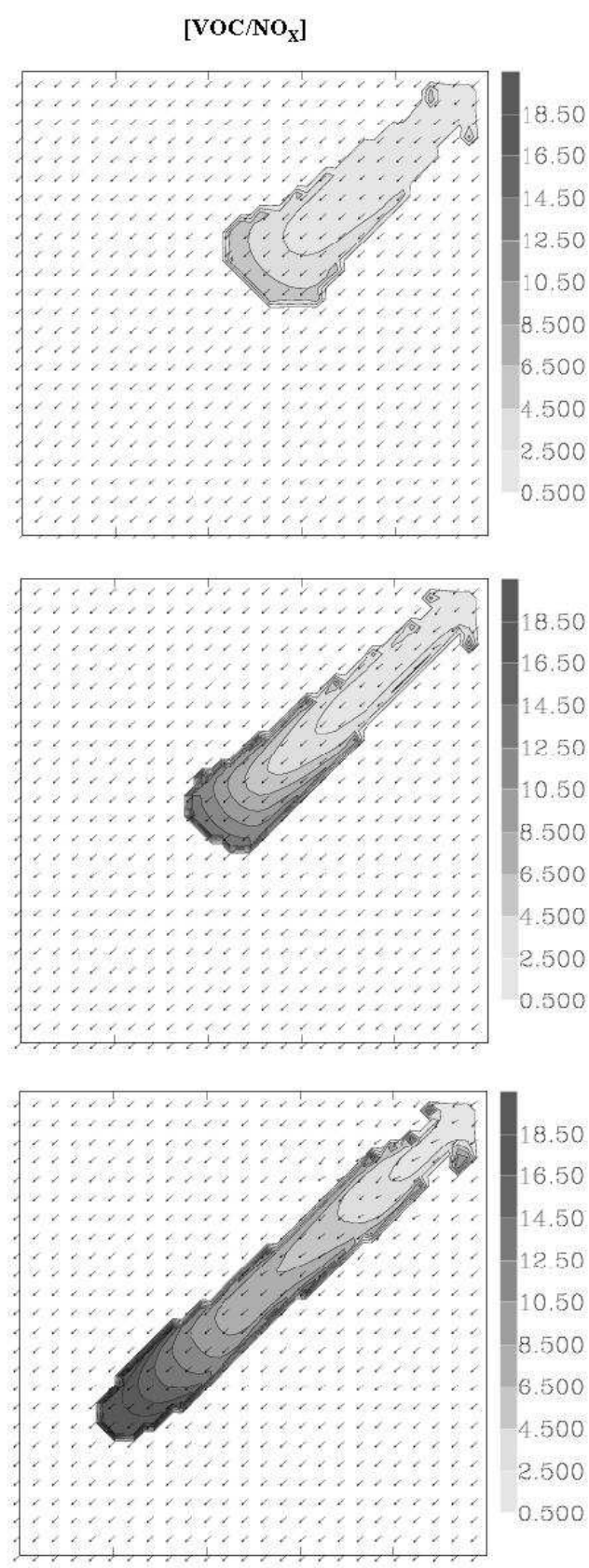

(c)

Fig. 7. As Fig. 6, for Martigues case (MT-NOBIO simulation).

4.5 Biogenic impact on the anthropogenic ozone plume

\subsubsection{Ozone concentrations}

Figures $8 \mathrm{a}$ and $\mathrm{b}$ show the predicted diurnal cycle of maximum ozone concentrations in the model domain when isoprene emissions were included in the simulations $(B I O)$ for different TOWN-FOREST distances $\left(d_{1}-\right.$ the shortest to $d_{4}-$ the longest. The distances are given be- tween the centers of the sources, Fig. 3) and for MS and $M T$ scenarios. The relative impact of isoprene emissions on the maximum ozone concentration was calculated as $W_{c}=\frac{\left[O_{3}\right]_{\max }^{B I O}-\left[O_{3}\right]_{\max }^{O O B I O}}{\left[O_{3}\right]_{\max }^{N O B I O}}$. The daily evolution of $W_{c}$ is shown in Figs. 8c and $8 \mathrm{~d}$.

\section{MS scenario:}

The largest impact of biogenic isoprene emissions on the maximum ozone concentrations occurred at distance $d_{1}$, 


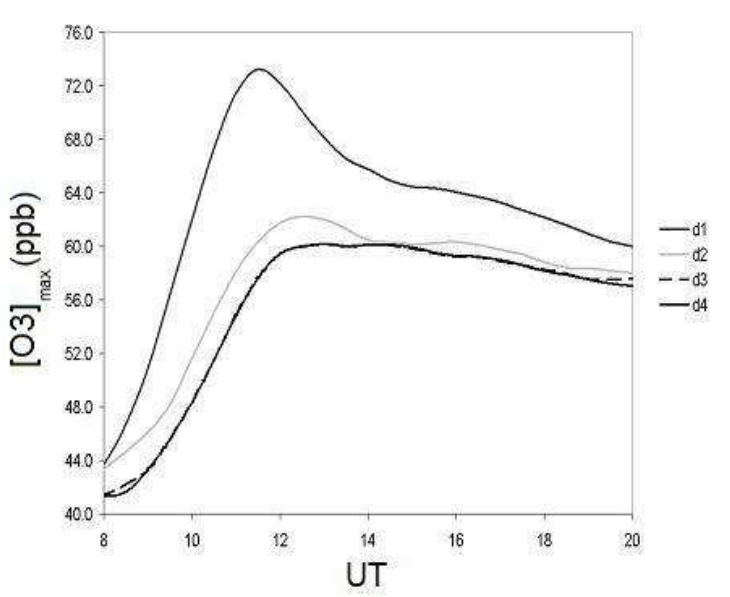

(a)

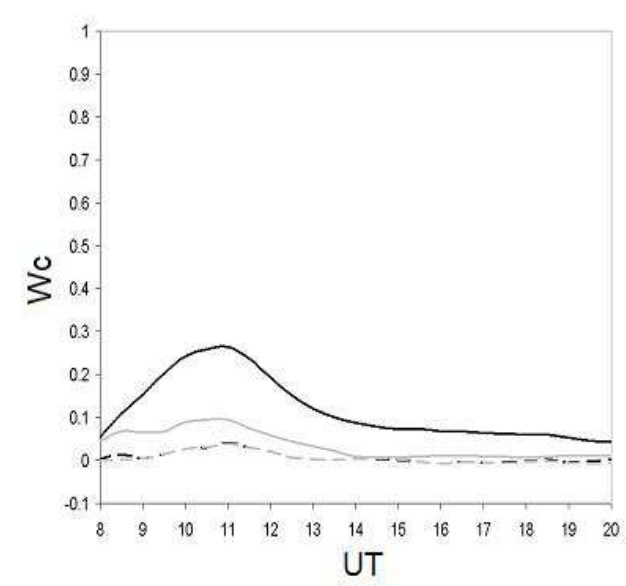

(c)

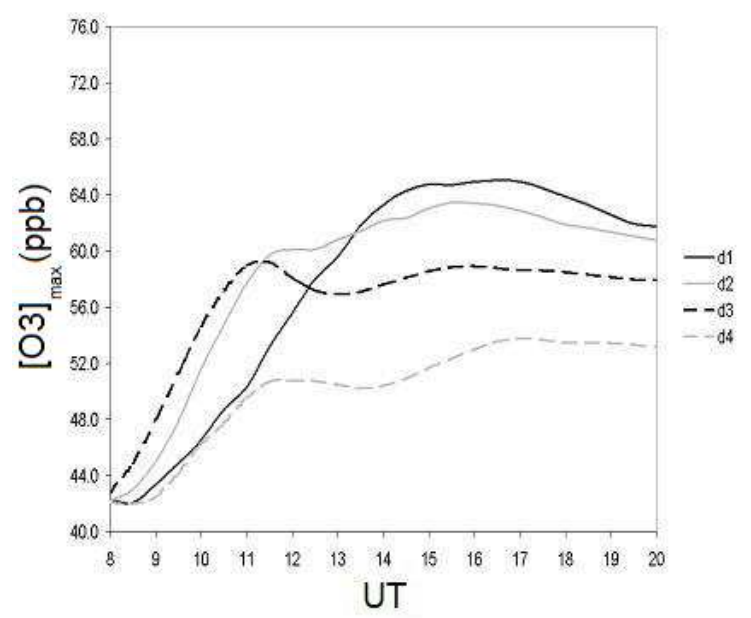

(b)

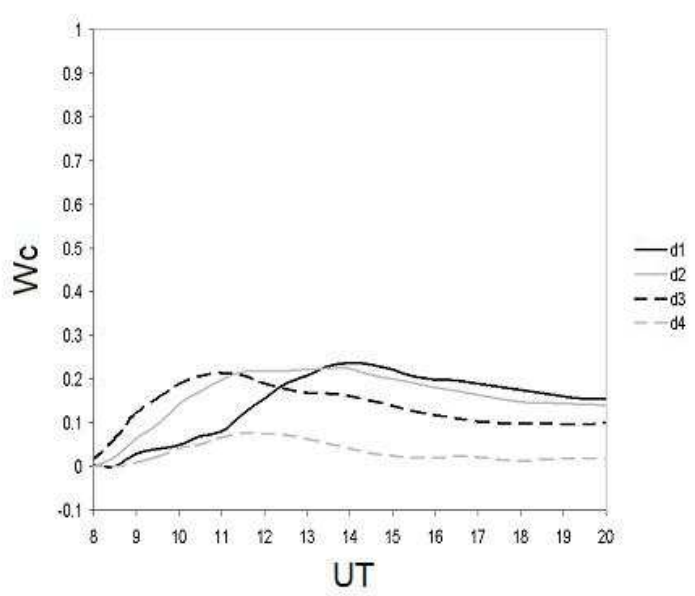

(d)

Fig. 8. Results of simulation taking into account biogenic emission over the FOREST area. (a) Evolution of the ozone maximum concentration in the $M S$ case for different downwind distances between TOWN and FOREST ( $d_{1}$ to $\left.d_{4}\right)$; (b) Same as (a) for the MT scenario; (c) Evolution of the relative contribution of isoprene emission to ozone maximal concentration $W_{c}$ (see definition in the text) in the $M S$ case; (d) Same as (c) for the $M T$ scenario.

where $W_{c}$ reached $\sim 37 \%$ around 11:00 UT (Fig. 8a). A $\mathrm{VOC} / \mathrm{NO}_{x}$ ratio $<2.5$ associated to significant $\mathrm{NO}_{x}$ concentrations (Fig. 6b) induced a "VOC sensitive" chemical regime (Sillman, 1999) in the simulated MS-NOBIO anthropogenic plume. Consequently, isoprene emissions (MS-BIO simulation) had a large impact on the ozone production in this case. This impact was weaker for the $d_{2}$ distance $\left(W_{c} \sim 10 \%\right.$, Fig. 8a) since the reference anthropogenic $\mathrm{VOC} / \mathrm{NO}_{x}$ ratio increased rapidly with downwind distance (Fig. 6b). After 12:00, the reference $\mathrm{VOC} / \mathrm{NO}_{x}$ ratio characterizing the anthropogenic plume at $d_{1}$ and $d_{2}$ increased with time (Fig. 6b); therefore, $W_{c}$ decreased in spite of higher isoprene emissions in the afternoon. At distances $d_{3}$ and $d_{4}$, the reference pollutant plume had already evolved towards a " $\mathrm{NO}_{x}$ sensi- tive" regime characterized by high $\mathrm{VOC} / \mathrm{NO}_{x}$ ratio (Sillman, 1999). Thus, at this point where the plume reached the FOREST, the isoprene emissions had little impact on the ozone concentration in the plume (Fig. 8a).

Figures $9 \mathrm{a}$ and $\mathrm{b}$ show respectively the surface ozone concentration and $\mathrm{VOC} / \mathrm{NO}_{x}$ ratio evolution for the $M S-B I O$ simulation, considering a TOWN-FOREST distance equal to $d_{1}$. When comparing Fig. 9a to reference plumes (Fig. 6a), we note that, in addition to maximum ozone concentrations, the FOREST isoprene emissions also impacted the shape and extent of the ozone plume. In this $M S-B I O$ simulation, the location of the maximum ozone concentration was shifted downwind. A comparison between Figs. $6 \mathrm{~b}$ and $9 \mathrm{~b}$ shows that the $\mathrm{VOC} / \mathrm{NO}_{x}$ ratio increased more rapidly when 
$\left[\mathrm{O}_{3}\right]$
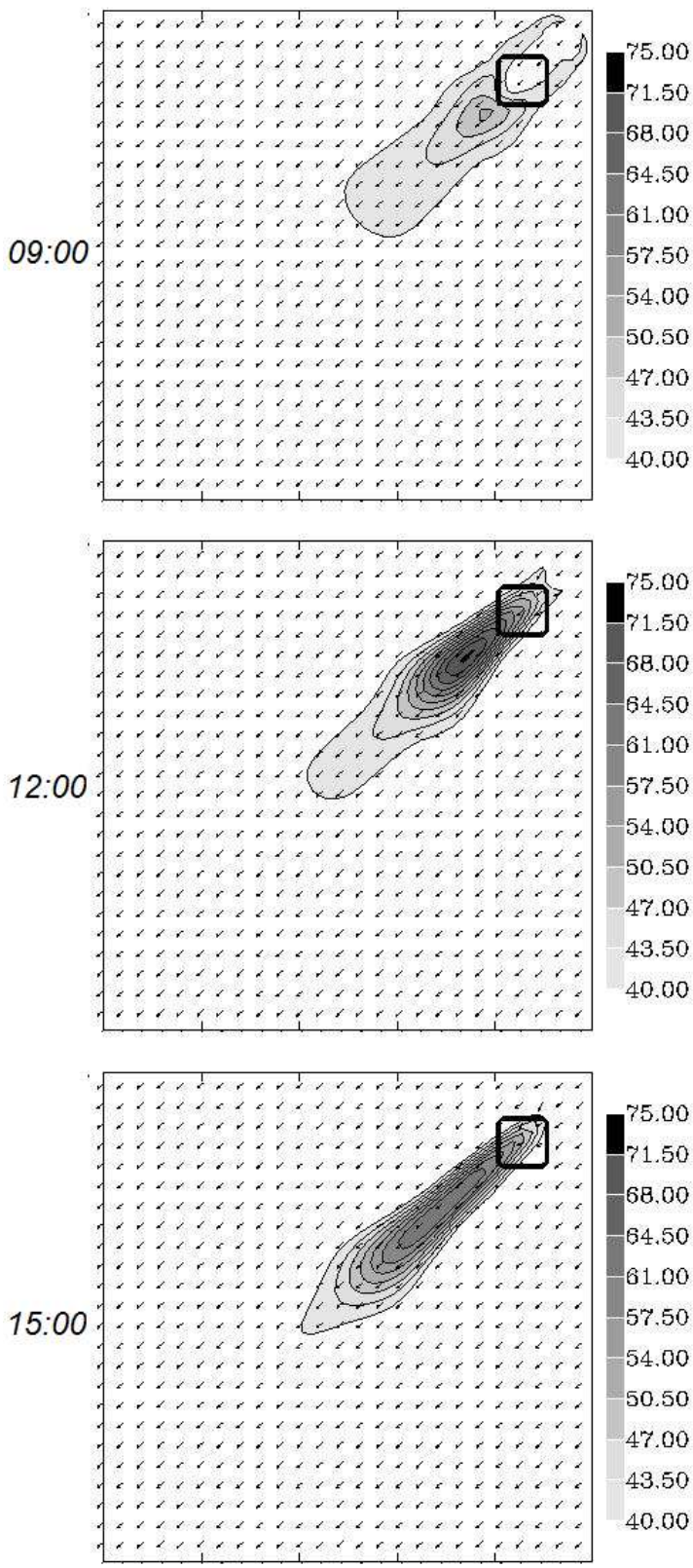

(a)
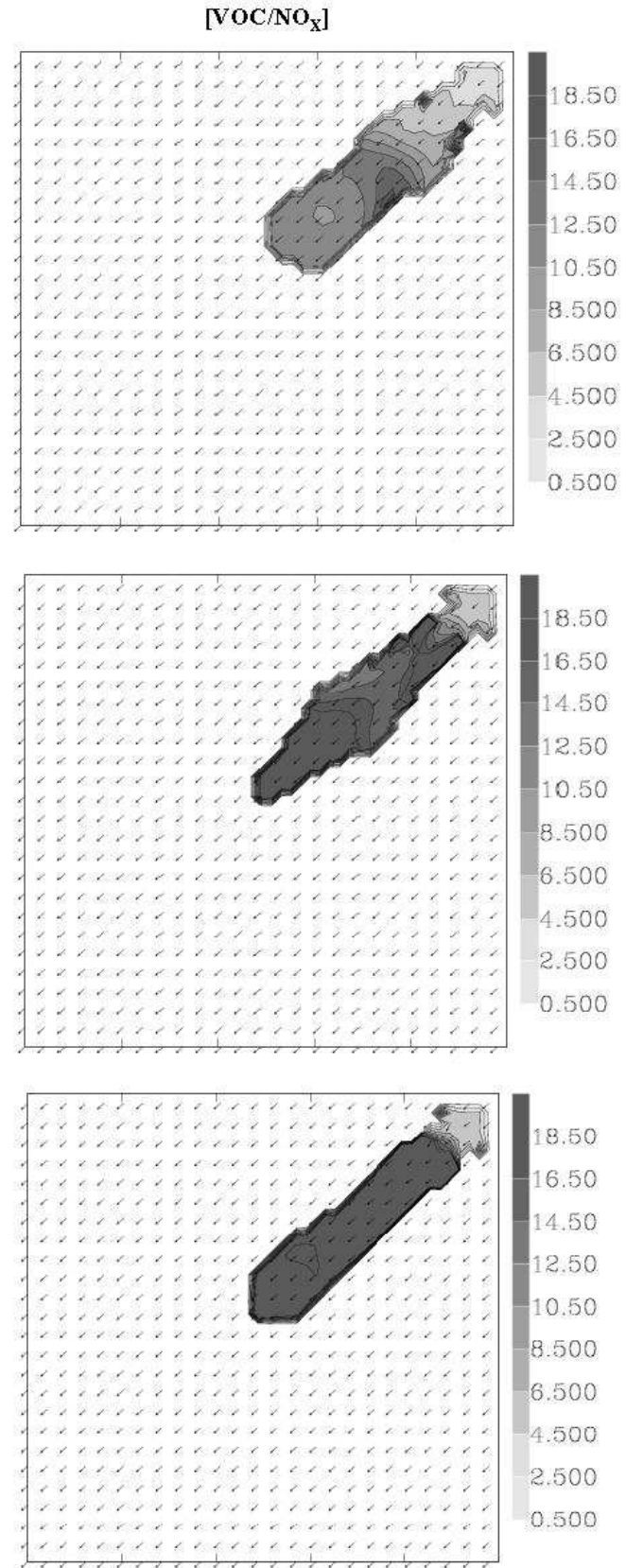

(b)

Fig. 9. Simulation results taking into account biogenic emission for the $M S$ case with the $d_{1}$ TOWN-FOREST distance (the square represent the FOREST). Horizontal section (at $10 \mathrm{~m}$ above ground) are given at 09:00 UT, 12:00 UT and 15:00 UT. (a) Ozone concentration field (ppb). (b) VOC/NOx ratio (ppbC/ppb).

the isoprene source was located closer to the anthropogenic source. The biogenic isoprene emission over the FOREST area induced a faster maturation of the plumes from a "VOC sensitive" regime to a "NO$x$ sensitive" one (see also Sillman, 1999).

\section{MT scenario:}

The reference $M T-N O B I O$ simulation at 09:00 UT was characterized by a $\mathrm{VOC} / \mathrm{NO}_{x}$ ratio $<2.5$ (Fig. 7b). These conditions defined a VOC-sensitive regime prevailing for the $d_{1}, d_{2}$, and $d_{3}$ distances, and to a lesser extent for $d_{4}$. Consequently, in the $M T-B I O$ simulations, the ozone formation was sensitive to isoprene emissions even moderated in the morning (Fig. 8d). However, the ozone production in this scenario was also limited by high $\mathrm{NO}_{x}$ concentrations in the 
$\left[\mathrm{O}_{3}\right]$
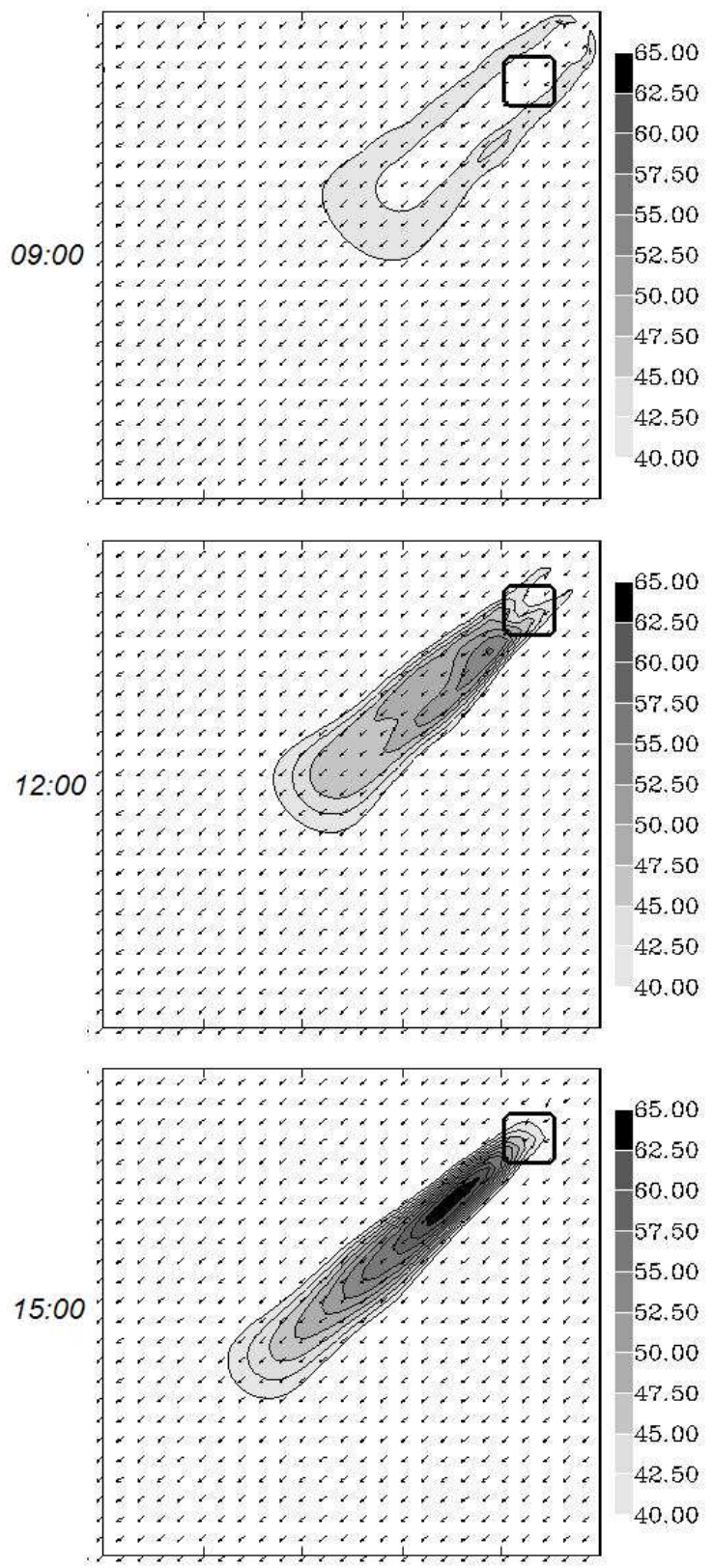

(a)
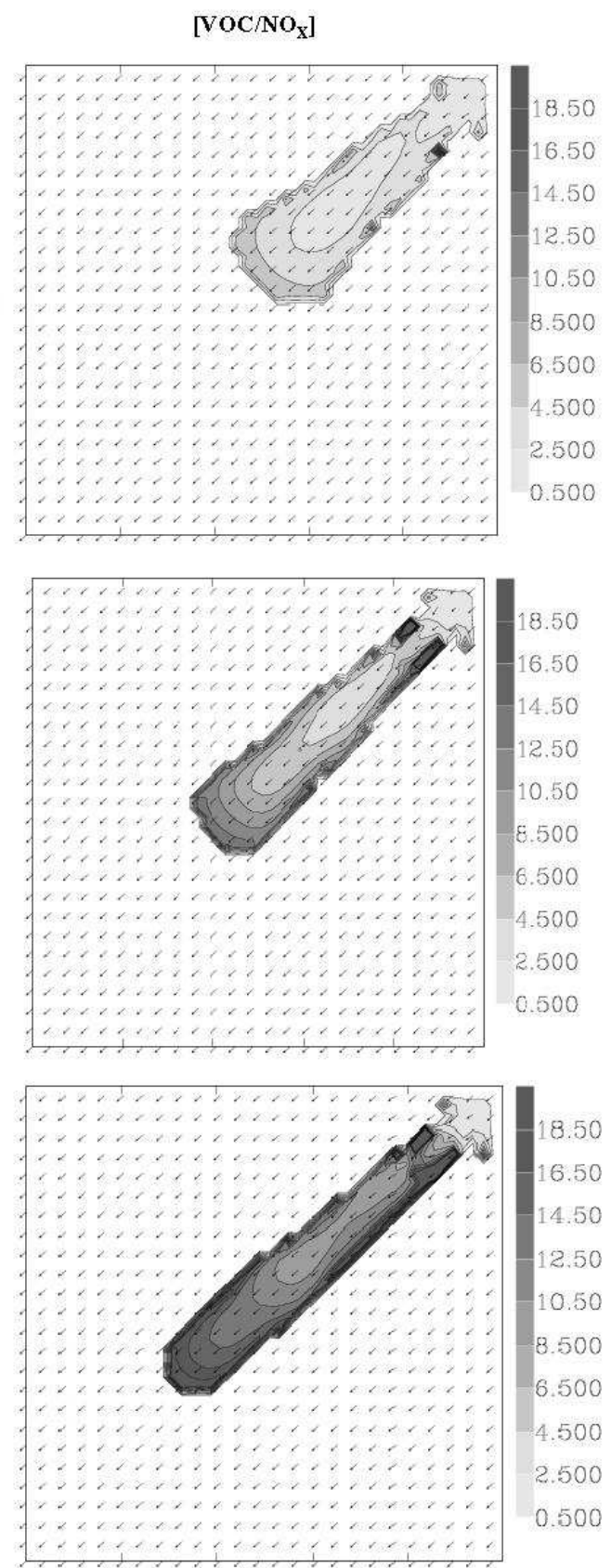

(b)

Fig. 10. Same as Fig. 9 for the $M T$ scenario (the square represent the FOREST).

anthropogenic plumes (particularly on the morning) as discussed in Sect. 4.4 (see also Fig. 7a). As a result of the balance between VOC-sensitive and $\mathrm{NO}_{x}$-saturated region, the maximum biogenic impact in the morning occurred at the distance $d_{3}$, with a relative increase $W_{c}$ reaching almost $30 \%$ at 11:00 UT (Fig. 8d). In this case, $d_{3}$ represented the optimal distance for which the $\mathrm{VOC} / \mathrm{NO}_{x}$ ratio was favorable to biogenic ozone formation. Later in the day, as the $\mathrm{NO}_{x}$ saturated area extension reduces, the optimal VOC sensitive con- ditions were observed at distances closer to the TOWN (cf Fig. 7b): consequently, the maximum relative impacts $\left(W_{c}\right)$ of biogenic emission were found successively for $d_{3}, d_{2}$ and $d_{1}$ TOWN-FOREST distances (Figs. 8b and 8d).

For the distance $d_{1}$ (i.e. very close to the TOWN source), the maximum biogenic impact $W_{c}$ of $32 \%$ occurred around 14:00 UT, when the isoprene emissions were at their maximum. The highest value of the maximum ozone concentration also happened at distance $d_{1}$ between 15:00 UT and 


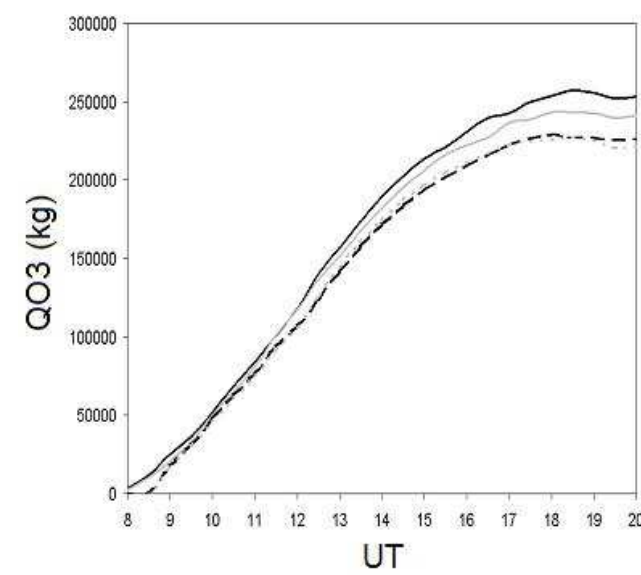

(a)

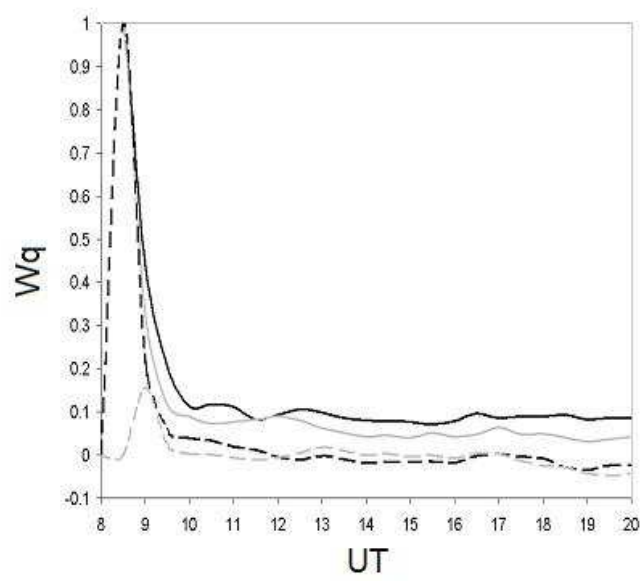

(c)

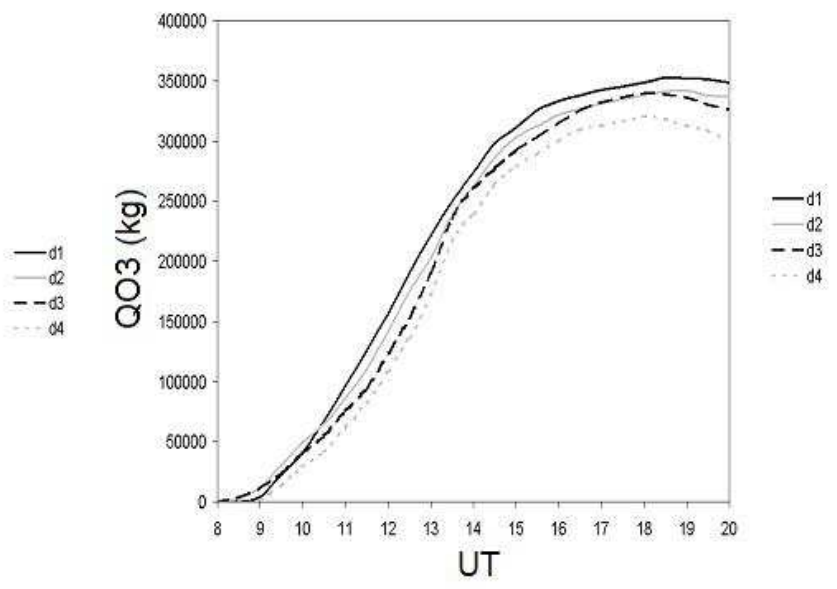

(b)

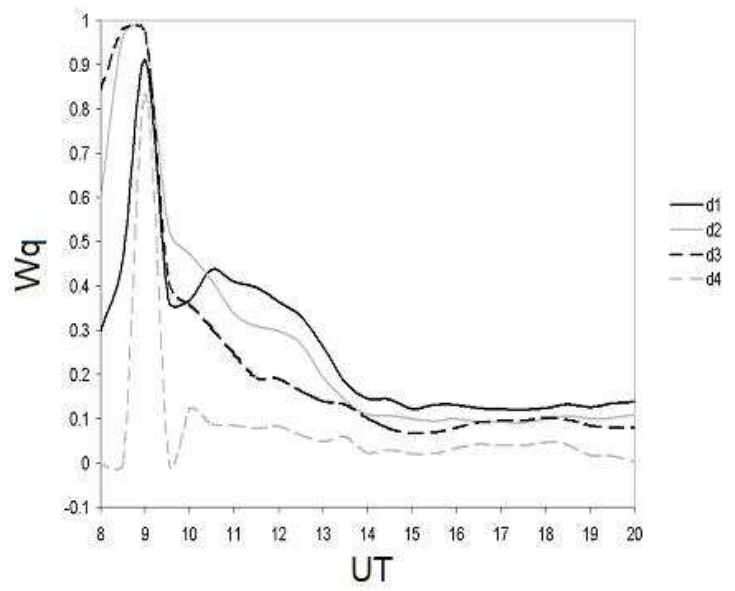

(d)

Fig. 11. (a) Simulation results taking into account biogenic emission over the FOREST area. (a) Total ozone amount in the plume for the $M S$ situation, function of $d_{1}$ to $d_{4}$ TOWN-FOREST distances; (b) Same as (a) for $M T$ scenario; (c) Evolution of the relative contribution of isoprene emission to the total ozone amount $W_{Q}$ (see definition in the text) in the $M S$ case; (d) Same as (c) for the $M T$ scenario.

17:00 UT (Fig. 8b). As illustrated on Figs. 7a and 10a, the pattern of the ozone plume was significantly modified by the biogenic source: at 12:00 UT, the biogenic VOC emissions were sufficient to enable ozone production, whereas ozone production was inhibited by $\mathrm{NO}_{x}$-saturated conditions in the reference simulation. At 15:00 UT an ozone surface concentration maximum appeared downwind of the forest. Moreover, as discussed for the $M S$ scenario, diurnal cycle of the $\mathrm{VOC} / \mathrm{NO}_{x}$ ratio was also strongly affected, indicating an acceleration of the downwind plume maturation resulting from isoprene emissions (Fig. 7c vs. Fig. 10b).

\subsubsection{Integrated ozone amount}

In the Sect. 4.5.1, the impact of biogenic sources was discussed in term of concentrations, which are relevant for the comparison with pollution thresholds. Complementarily, the evaluation of the total ozone amount contained in the plume $Q_{O 3}(\mathrm{~kg})$ can give a spatially and temporally integrated insight of the biogenic ozone production during the day. Here, $Q_{O 3}(\mathrm{~kg})$ was calculated for the whole 3-dimensional domain as the sum of ozone amounts contained in the cells for which the ozone concentration exceeded $40 \mathrm{ppb}$ (i.e. the initial and forcing concentration). The relative increase in the total mass of ozone resulting from biogenic precursors, compared to a pure anthropogenic plume, was calculated as: $W_{Q}=\frac{Q_{O 3}^{B I O}-Q_{O 3}^{N O B I O}}{Q_{O 3}^{N O B I O}}$. 
Table 2. Maximum values for ozone concentration $\left(\left[\mathrm{O}_{3}\right]_{\max }\right)$, ozone total amount $\left(\mathrm{QO}_{3}\right)$ and relative contribution of isoprene emissions $\left(\mathrm{W}_{c} \max \right)$.

\begin{tabular}{|c|c|c|c|c|}
\hline \multicolumn{5}{|l|}{ MS-case } \\
\hline & $\mathrm{d}_{1}$ & $\mathrm{~d}_{2}$ & $d_{3}$ & $\mathrm{~d}_{4}$ \\
\hline $\begin{array}{c}{\left[\mathrm{O}_{3}\right]_{\max }(\mathrm{ppb})} \\
\mathrm{QO}_{3}(\mathrm{~kg}) \\
\mathrm{W}_{\mathrm{c}} \max (\%)\end{array}$ & $\begin{array}{c}73 \text { at } 11 \text { a.m. } \\
250000 \text { at } 6 \text { p.m. } \\
37 \text { at } 11 \text { a.m. }\end{array}$ & $\begin{array}{c}62 \text { at } 12: 30 \text { a.m. } \\
230000 \text { at } 6 \text { p.m. } \\
10 \text { at } 11 \text { a.m. }\end{array}$ & $\begin{array}{c}60 \text { at } 3 \text { p.m. } \\
215000 \text { at } 6 \text { p.m. } \\
5 \text { at } 11 \text { a.m. }\end{array}$ & $\begin{array}{c}60 \text { at } 3 \text { p.m. } \\
215000 \text { at } 6 \text { p.m. } \\
5 \text { at } 11 \text { a.m. }\end{array}$ \\
\hline \multicolumn{5}{|l|}{ MT-case } \\
\hline & $\mathrm{d}_{1}$ & $\mathrm{~d}_{2}$ & $d_{3}$ & $\mathrm{~d}_{4}$ \\
\hline $\begin{array}{c}{\left[\mathrm{O}_{3}\right]_{\max }(\mathrm{ppb})} \\
\mathrm{QO}_{3}(\mathrm{~kg}) \\
\mathrm{W}_{\mathrm{c}} \max (\%)\end{array}$ & $\begin{array}{c}66 \text { at } 4 \text { p.m. } \\
350000 \text { at } 6 \text { p.m. } \\
32 \text { at } 14 \text { a.m. }\end{array}$ & $\begin{array}{c}63 \text { at } 4 \text { p.m. } \\
340000 \text { at } 6 \text { p.m. } \\
30 \text { at } 14 \text { a.m. }\end{array}$ & $\begin{array}{c}60 \text { at } 11 \text { p.m. } \\
340000 \text { at } 6 \text { p.m. } \\
30 \text { at } 11 \text { a.m. }\end{array}$ & $\begin{array}{c}52 \text { at } 5 \text { p.m. } \\
310000 \text { at } 6 \text { p.m. } \\
10 \text { t } 12 \text { a.m. }\end{array}$ \\
\hline
\end{tabular}

\section{MS scenario}

The maximum ozone production in the plume was obtained for the $d_{1}$ TOWN-FOREST distance with a total ozone amount reaching $260.10^{3} \mathrm{Kg}$ at 18:00 UT (Fig. 11a). The final amount of ozone was approximately $240.10^{3} \mathrm{~kg}$ for the $d_{2}$ case (Fig. 11a) for the same time. The proximity of FOREST and TOWN areas favored the availability of anthropogenic $\mathrm{NO}_{x}$ reacting with biogenic compounds, as discussed in the Sect. 4.5.1. Moreover, the proximity of FOREST and TOWN areas also caused a longer interaction between the anthropogenic plume and the forest area during daytime. No significant differences were observed for $d_{3}$ and $d_{4}$ TOWNFOREST distances, which both resulted in total ozone mass of around $230.10^{3} \mathrm{~kg}$.

From 08:00 UT to 10:00 UT very large value of $W_{Q}$ (Fig. 11c) were observed, indicating relatively strong ozone production resulting from isoprene emissions that mixed with available $\mathrm{NO}_{x}$. However, the corresponding absolute ozone production was small (Fig. 11a), and the quantitative value of $W_{Q}$ was highly uncertain $\left(\mathrm{Q}_{O 3}^{N O B I O}\right.$ terms close to zero). More significantly, from 10:00 UT to 20:00 UT, the ozone production increased and the calculated $W_{Q}$ stabilized, around $10 \%$ for $d_{1}$ and $8 \%$ for $d_{2}$. The biogenic contributions for the $d_{3}$ and $d_{4}$ scenarios were fairly insignificant, with no major interaction between the forest emissions and the anthropogenic plume for these distances (Sect. 4.5.1).

\section{MT scenario}

The in-plume ozone amounts obtained in the MT scenario were larger than those from the $M S$ scenario. The maximum production was found for the $d_{1}$ TOWN-FOREST distance, with a value reaching $350.10^{3} \mathrm{Kg}$ at the end of the simulation (Fig. 11b). The amount of ozone produced with the $d_{2}$ distance reached $350.10^{3} \mathrm{Kg}$ and was slightly higher compared to the $d_{3}$ case (Fig. 11b). As discussed in the $M S$ scenario, $W_{Q}$ was highly sensitive to biogenic isoprene emissions from 08:00 UT to 10:00 UT. For the period 10:00 UT-14:00 UT, significant amounts of ozone were produced corresponding to high values of $W_{Q}$ (Fig. 11c). Figure $11 \mathrm{~d}$ indicates that the biogenic isoprene emissions impacted ozone production in the plume for all distances. The global decrease of $W_{Q}$ is dependent upon the $\mathrm{VOC} / \mathrm{NO}_{x}$ ratio, which increased over the day as the ozone plume developed. The maximum biogenic impact on the ozone production was found for the $d_{1}$ distance, with a stable value of $W_{Q}=17 \%$ (at 18:00 TU) (Fig. 11d). For the distances $d_{2}$ and $d_{3}$, we calculated a final impact around $10 \%$, whereas we obtained a stable value of $W_{Q}=4 \%$ for the distance $d_{4}$ both around 18:00 TU.

In Table 2, all the values for the maximum simulated ozone concentrations $W_{c}$, and $W_{q}$ are reported.

\section{Conclusion}

A simple isoprene emission scheme designed for meso-scale atmospheric chemistry studies has been introduced. In the first part of this paper, validations of this scheme were carried out at the local scale and for diverse ecosystem canopies (Boreal, Tropical, Temperate and Mediterranean forests). Results showed that the model has been able to reproduce satisfactorily (correlation coefficient ranging from 0.88 to 0.91 ) the diurnal cycle of isoprene emissions. A slight tendency of the model to overestimate isoprene fluxes has nevertheless been addressed. The model bias bears notably upon the difficulty to accurately represent leaf temperatures with a simple surface energy budget, especially for a Mediterranean-type forest. However, these results encouraged us to consider this emission scheme suitable for regional chemistry modeling.

In the second part of the paper, this isoprene emission scheme was used with the atmospheric chemistry model Meso-NH-C. Through a simplified approach, the interactions 
of two typical anthropogenic pollutant plumes with an isoprene emission source (from a Mediterranean oak ecosystem) have been studied. Particularly, the impact of diverse TOWN - FOREST distances (from $d_{1}=$ adjacent to $d_{4} \sim 130 \mathrm{~km}$ between TOWN and FOREST centers) on ozone surface concentrations and total ozone production in urban plumes was investigated for a typical wind velocity of $4.2 \mathrm{~m} \cdot \mathrm{s}^{-1}$.

The first urban source considered (typical of Marseille) was characterized by a relatively high $\mathrm{VOC} / \mathrm{NO}_{x}$ emission ratio. The impact of forest isoprene emissions on ozone formation in that urban plume was found to be most important in close proximity to the TOWN area. In such a configuration, biogenic isoprene was found to contribute up to $37 \%$ of the maximum simulated ozone concentration, and $11 \%$ of the total amount of ozone present in the plume at the end of the afternoon. Due to the specificity of its emissions, the Marseille anthropogenic plume rapidly evolved towards a $\mathrm{NO}_{x}$ sensitive chemical regime. The impact of isoprene emissions on the ozone in this plume decreased substantially when the TOWN-FOREST distance increased for distances $>70 \mathrm{~km}$.

In the second modeling scenario, the urban source (typical of Martigues) was characterized by a low $\mathrm{VOC} / \mathrm{NO}_{x}$ emission ratio. Isoprene emissions were shown to significantly impact ozone formation in the plume at distances up to $d_{3}$ $(\sim 100 \mathrm{~km})$. The biogenic emissions had little impact when the source was located at $d_{4}$. Due to the VOC-sensitive and $\mathrm{NO}_{x}$-saturated conditions prevailing in this anthropogenic plume, the biogenic isoprene emissions contributed to $>30 \%$ of the maximum simulated ozone concentrations in the morning hours for the $d_{3}(100 \mathrm{~km})$ distance. However, as the $\mathrm{NO}_{x}$ concentrations in the urban plume decreased during the day for this scenario, the maximum impact of isoprene emissions on ozone production shifted toward the TOWN area $\left(d_{2}\right.$ and $d_{1}$ ). For $d_{1}$ (forest adjacent to the town), ozone maximum surface concentrations were enhanced by isoprene emissions as much as $+32 \%$ in the afternoon, when biogenic emissions peaked. Total ozone production in the plume was enhanced by $17 \%$ due to biogenic precursors at the $d_{1}$ distance at the end of the day. Contributions calculated for larger TOWNFOREST distances were also significant.

In this idealized study, the different results obtained for the $d_{1}$ to $d_{4}$ distances were sensitive to a number of factors, primarily the plume advection velocity. A change in this latter parameter would affect the time scale of interaction between polluted plume and forest (diffusion of the plume, residence time of primary pollutants above forest, etc). The initial chemistry conditions would have been also a factor modulating the concentrations obtained in this study, and which deserve to be further investigated. As mentioned by Trainer et al. (1995), the simulation of ambient ozone concentrations requires a complex interaction between the photochemistry and meteorology. Together, these factors determine the location and the magnitude of the peak ozone concentrations in urban plumes. The photochemical formation of ozone de- pends strongly on the degree of reactivity of the ambient environment. Ryerson et al. (2001) observed that high ambient isoprene concentrations can enhance the production of ozone formation under specific ambient $\mathrm{NO}_{x}$ conditions. But, the ambient $\mathrm{NO}_{x} / \mathrm{VOC}$ ratio can lead to a less reactive ambient environment with less ozone produced.

Idealized regional chemistry model that uses a simplified landscape is an interesting tool that enables the isolation of individual processes occurring at regional scales, including the impact of biogenic sources in the production of ozone within urban plumes. This model framework can be particularly useful when used to simulate well-documented areas, and may eventually be applied to investigate various regulatory policies. Further, evaluating and forecasting BVOCs emissions can be used by regional air quality scientists to act upstream in controlling transport and/or industrial emissions in regions characterized by strong biogenic VOC sources.

Acknowledgements. Many thanks to J. Fuentes and C. Geron for providing experimental data of isoprene and surface fluxes above the boreal and Duke forests. We would also like to thank S. Rambal, P. Bouchou and A. Fotiadi for their work in the Mediterranean forest.

Edited by: A. B. Guenther

\section{References}

Baldocchi, D. D, Fuentes, J. D, Bowling, D. R., Turnispeed, A. A., and Monson, R. K.: Scaling isoprene fluxes from leaves to canopies: test cases over a boreal aspen and a mixed species temperate forest, J. Appl. Meteor., 38, 885-898, 1999.

Calvet, J. C, Noilhan, J., Roujean, J-L, Bessemoulin, P., Cabelguenne, M., Olioso, A., and Wigneron, J. P.: An interactive vegetation SVAT model tested against data from six contrasting sites, Agricultural Forest and Meteorology, 92, 73-95, 1998.

Crassier, V., Suhre, K., Tulet, P., and Rosset, R.: Development of a reduced chemical scheme for use in mesoscale meteorological models, Atmos. Environ., 52B, 290-320, 2000.

Cros, B., Durand, P., Frejafon, E., Kottmeïer, C., Perros, P. E., Peuch, V.-H., Ponche, J.-L., Robin, D., Saïd, F., Toupance, G., and Wortham, H.: The ESCOMPTE programme: an overview, Atmos. Res., 69, 3-4, 241-279, 2004.

Delmas, R., Druilhet, A., Cros, B., Durand, P., Delon, C., Lacaux, J., Brustet, J., Serça, D., Affre, C., Guenther, A., Greenberg, J., Baugh, W., Harley, P., Klinger, L., Ginoux, P., Brasseur, G., Zimmerman, P., Grégoire, J., Janodet, E., Tournier, A., and Perr, P.: Experiment for Regional Sources and Sinks of Oxidants (EXPRESSO): An overview, J. Geophys. Res., 104, 30 609-30 624, 1999.

Fuentes, J. D., Wang, D., and Gu, L.: Seasonnal variations in isoprene emissions from a boreal aspen forest, J. Appl. Meteor., 38, 855-869, 1999.

Geron, C., Nie, D., Arnts, R., Sharlkey, T., Singsaas, E., Vanderveer, P., Guenther, A., Sickles, J., and Kleindienst, T.: Biogenic isoprene emission: Model evaluation in a southeastern United States bottomland deciduous forest, J. Geophys. Res., 102, NO D15, pages 18 889-18 901, 1997. 
Guenther, A., Zimmerman, P., Harley, P., Monson, R., and Fall, R.: Isoprene and monoterpenes emission rate variability: model evaluation and sensitivity analysis, J. Geophys. Res., 98, 12 609$12617,1993$.

Guenther, A., Zimmerman, P., and Wildermuth, M.: Natural volatile organic compound emission rate estimate for U.S. woodland landscapes, Atmos. Environ., 28, 1197-1210, 1994.

Guenther, A., Hewitt, C., Erickson, D., Fall, R., Geron, C., Graedel, T., Harley, P., Klinger, L., Lerdau, M., McKay, W., Pierce, T., Scholes, B., Steinbrecher, R., Tallamraju, R., Taylor, J., and Zimmerman, P.: A global model of natural volatile organic compound emissions, J. Geophys. Res., 100, 8873-8892, 1995.

Guenther, A. and Hills, A.: Eddy covariance measurement of isoprene fluxes, J. Geophys. Res., 103, No D11, 13 145-13 152, 1998.

Guenther, A.: Modeling Biogenic VOC Emissions to the Atmosphere, in: Reactive Hydrocarbons in the Atmosphere, edited by: Hewitt C., Academic Press, 97-118, 1999a.

Guenther, A., Geron, C., Pierce, T., Lamb, B., Harley, P., and Fall, R.: Natural emissions of non-methane volatile organic compounds, carbon monoxyde, and oxides of nitrogen from North America, Atmos. Environ., 34, 2205-2230, 2000.

Hewitt, C. N., Owen, S., Jackson, A., King, B., Arya, R., Wheeler, P., and Scholefield, P.: The BEMA project: Summary report on the BEMA field campaign at Montpellier, June and October 1995, Report on the 2nd BEMA measuring campaign Montpellier-France, report EUR16449 EN 1996, 57-64, June 1995.

Kesselmeier, J. and Staudt, M.: Biogenic volatile organic compounds (VOC): An overview on emission, Physiology and Ecology, J. Atmos. Chem., 33, 23-88, 1999.

Masson, V., Champeaux, J.-L., Chauvin, F., Meriguet, C., and Lacaze, R.: A global database of Land Surface Parameters at $1 \mathrm{~km}$ Resolution in Meteorological and Climate Models, J. Clim., 16, 9 1261-1282, 2003.

Masson, V.: A physically based scheme for the urban energy budget in atmospheric models, Boundary Layer Meteorology, 94, 357$397,2000$.

Noilhan, J. and Planton, S.: A simple parameterization of land surface processes for meteorological models, Monthly Weather Review, 117, 536-549, 1989.

Otter, L. B., Guenther, A., and Greenberg, J.: Seasonal and spatial variations in biogenic hydrocarbon emissions from southern Africa savannas and woodlands, Atmos. Environ., 36, 42654275, 2002.

Owen, S., Boissard, C., Hagenlocher, B., and Hewitt, C. N.: Field studies of isoprene emissions from vegetation in the Northwest Mediterranean region, J. Geophys. Res., 103, 25 499-25 511, 1998.
Owen, S. M., Boissard, C., and Hewitt, C. N.: Volatile organic compounds (VOCs) emitted from 40 Mediterranean plant species: VOC speciation and extrapolation to habitat scale, Atmos. Environ., 35, 5393-5409, 2001.

Roselle, S. J.: Effects of biogenic emission uncertainties on regional photochemical modeling of control strategies, Atmos. Environ., 28, 1157-1772, 1994.

Roujean, J-L.: A tractable physical model of shortwave radiation interception by vegetative canopies. J. Geophys. Res., 101, D5, 9523-9532, doi:10.1029/96JD00343, 1996.

Serça, D., Guenther, A., Klinger, L., Vierling, L., Harley, P., Druilhet, A., Greenberg, J., Baker, B., Roberts, G., Bouka-Biona, C., and Loemba-Ndembi, J.: EXPRESSO flux measurements at upland and lowland Congo tropical forest site, Tellus, 53B, 220234, 2001.

Sillman, S.: The relation between ozone, $\mathrm{NO}_{\mathrm{x}}$ and hydrocarbons in urban and polluted rural environments, Atmos. Environ., 33, 1821-1845, 1999.

Solmon, F., Sarrat, C., Serça, D., Tulet, P., and Rosset R.: Isoprene and monoterpenes biogenic emissions in France: modeling and impact during a regional pollution episode, Atmos. Environ., 38(23), 3853-3865, 2004.

Stockwell, W. R., Kirchner, F., and Kuhn, M.: A new mechanism for regional atmospherical modeling, J. Geophys. Res., 102 $25847-25879,1997$.

Suhre, K., C., Mari., Bates, T. S., Johnson, J. E, Rosset, R., Wang, Q., Bandy, A. R., Blake, D. R., Eisele, F. L., Kok, G. 1., Mauldin III, R. L., Prévot, A., Schillawski, R. D., and Thornton, D. C.: Physico-chemical modeling of the First Aerosol Characterisation Experiment (ACE-1) Lagrangian B.1, a moving column approach, J. Geophys. Res., 103, D13, 16433-16455, 1998.

Tsigaridis, K. and Kanakidou, M.: Importance of volatile organic compounds photochemistry over a forested area in central Greece, Atmos. Environ., 36, 3137-3146, 2002.

Tulet, P., Maleej, A., Crassier, V., and Rosset, R.: An episode of photooxidant plume pollution over the Paris region, Atmos. Environ., 33, 1651-1662, 1999.

Tulet, P., Crassier, V., Solmon, F., Guedalia, D., and Rosset, R.: Description of the MESO-NH-C model and application to a transboundary pollution episode between northern France and southern England, J. Geophys. Res., 108(D1), 4021, doi:10.1029/2000JD000301, 2003.

Wickert, B., Schwartz, U., Blank, P., John, C., Kuhlwein, J., Obermeier, A., and Friedrich, R.: Generation of an emission data base for Europe 1994, Proceedings of Eurotrack symposium, 98, 2, 255-265, 1999.

Xiaoshan, Z., Yujing, M., Wenzhi, S., and Yahui, Z.: Seasonal variations of isoprene emissions from deciduous trees, Atmos. Environ., 34, 3027-3032, 2000. 